\title{
Reading and Writing Characteristics of Cerebral Infarction Patients with or without Aphasia
}

\author{
Eun Ju Yeon', Yeo Jin Kim ${ }^{b}$, Duk L. Na ${ }^{c}$, Ji Hye Yoon ${ }^{d}$ \\ ${ }^{a}$ Department of Speech Pathology, Graduate School of Health Sciences, Hallym University, Chuncheon, Korea \\ ${ }^{b}$ Department of Neurology, Chuncheon Sacred Heart Hospital, Chuncheon, Korea \\ 'Department of Neurology, Samsung Medical Center, Sungkunkwan University School of Medicine, Seoul, Korea \\ ${ }^{d}$ Division of Speech Pathology and Audiology, College of Natural Sciences, Hallym University, Chuncheon, Korea
}

Correspondence: Ji Hye Yoon, PhD

Division of Speech Pathology and Audiology,

Hallym University, 1 Hallimdaehak-gil, Chuncheon

24252, Korea

Tel: +82-33-248-2224

Fax: +82-33-256-3420

E-mail: j.yoon@hallym.ac.kr

Received: July 9, 2018

Revised: August 19, 2018

Accepted: September 3, 2018

This material is based upon work supported by the Ministry of Trade, Industry \& Energy (MOTIE) of Korea under Industrial Technology Innovation Program (No. 10063384).

This research was supported by Hallym University Research Fund in 2018 (No. HRF-201806-009).

\begin{abstract}
Objectives: Even if left hemisphere damage occurs, aphasia may not be present if languagerelated areas are not involved. The change in cognitive ability due to brain damage may lead to alexia and agraphia, even in the absence of aphasia. The study examines the effects of aphasia on the performance capability and error aspects of reading and writing in patients with cerebral infarction. Methods: Twenty-four patients with cerebral infarction and 15 normal adults were enlisted to perform 60 reading tasks and 45 writing tasks. Results: First, aphasic patients showed significantly lower performance in reading (irregular and non-words) and writing (regular, irregular, and non-words) tasks than non-aphasic patients and normal subjects. Second, non-aphasic patients showed significantly lower performance in writing (non-words) tasks than the normal group. Conclusion: It appears that patients with cerebral infarction exhibit difficulty with reading and writing, which reveals a written language impairment. In particular, the non-word performance capability of both aphasic and non-aphasic patients was low in writing tasks in comparison with normal adults. This is the result of the fact that writing tasks involve more complex and higher order processes than reading tasks. Non-words are mostly processed through the phonological route, so this result implies the possibility that brain damage affects the phonological route; that is, a grapheme-to-phoneme conversion, regardless of the presence or absence of aphasia.
\end{abstract}

Keywords: Cerebral infarction, Aphasia, Alexia, Agraphia
뇌졸중은 인지장애, 운동장애, 감각소실 등의 증상과 더불어 (Lee, Kwon, \& Lee, 2000; Radomski \& Latham, 2008), 언어장애를 유발한다(Kim, 2012; Sinanović, Mrkonjić, Zukić, Vidović, \& Imamović, 2011). 언어장애는 대부분 뇌혈관장애에 속하는 뇌경색(cerebral infarction)이나 뇌출혈(cerebral hemorrhage)의 후유증으로 발생한다(Na, 2016). 뇌경색은 뇌혈관이 막히는 증상으로(Kim, $2012 ; \mathrm{Na}, 2016)$, 뇌출혈보다 약 5 배 정도 많이 발생하며 뇌졸중 전 체 진료 인원 중 $80 \%$ 이상을 차지한다(Ministry of Health and Welfare, 2017). 뇌경색의 병소는 피질, 피질하, 뇌간, 소뇌 순으로 많이 발병하는데(Song \& Hong, 2015) 이때 주로 우성 대뇌피질 및 피질하의 국소 병변으로 인해 언어사용의 어려움, 즉, 실어증이 발 생할 수 있다(Lee at el., 2001; Kwon, 2013).
실어증은 주로 말하기나 듣기와 같은 구어능력의 사용성이 저하 되는 것을 지칭하는데, 뇌손상은 구어능력의 어려움과 더불어 읽 기와 쓰기 등 문어능력 장애를 유발할 수 있다(Kim \& Na, 2001). 문어능력은 문자언어로 된 자료를 이해하고, 자신의 생각이나 느낌 을 문자언어로 표현할 수 있는 능력이며(Ryu, 2015), 삶의 모든 측면 에서 정보를 공유하고 전달하는 데 중요한 역할을 하기 때문에 (Kim, Park, \& Cha, 2011) 임상평가 시에 구어능력뿐만 아니라 문어 능력을 확인하는 것은 중요하다. 특히 실어증에서 관찰되는 읽기장 애는 범위와 중증도가 다양하며(Knollman-Porter, Wallace, Hux, Brown, \& Long, 2015), 실어증의 유형이나 중증도에 상관없이 쓰기 수행에 어려움을 겪는다는 보고(Nadeau, Rothi, \& Crosson, 2000) 를 통해 우리는 구어장애와 문어장애의 동반 가능성 및 구어와 문 
어의 관련성에 대한 임상적 관심을 확인할 수 있다. 그러나 한편으 로는 문어산출은 구어의 음운체계를 통하여 처리가 이루어질 수도 있고 또는 구어의 체계를 통하지 않고 이루어질 수도 있다. 즉, 문어 산출이 구어산출을 통하여 반드시 이루어지는 것은 아니며, 독립 적인 경로를 통하여 이루어질 수도 있다(Ha, Pyun, Hwang, $\mathrm{Yi}, \&$ $\operatorname{Sim}, 2013)$. 이에 구어와 문어의 차별성에 대한 연구들이 이어져 왔 으며, 구어 및 문어가 언어 표현이 생성되는 도구로서의 기제가 다 르기 때문에 수행력에서 차이가 날 수 있다는 주장(Yoo, 2009)도 있다. 또한 구어와 다르게 읽기와 쓰기는 글자라는 상징적 기호를 활용하므로 각 나라 문어체계의 고유한 특성이 장애에 반영되는 특성을 가진다. 따라서 읽기와 쓰기의 특성을 확인하기 위해서는 먼저 한국어의 문어체계를 살펴볼 필요가 있다.

문자언어에서는 문자가 나타내는 언어단위의 크기에 의해서 문 자체계를 구분할 수 있다. 단어를 형태소 따위로 세분하지 않고 그 대로 단위로 잡는 것을 표어문자(logograph, 예: 한자)라고 하며, 음 소나 음절을 한 단위로 잡고 거기에 문자의 한 요소를 결부시켜서, 철자에 의해 어형표기를 한 것이 표음문자이다. 이는 다시 음소를 단위로 하는 알파벳과 음절을 단위로 하는 음절문자(syllabary, 예: 가나, kana)로 구분되며, 음소문자는 한글에 해당된다(Kim, 2000). 한글은 자음과 모음으로 이루어진 표음문자로서 한 음절은 최소 2 자에서 최대 6 자의 낱글자인 자음과 모음 자소들의 조합으로 이루 어져 있다. 한글표기체계는 한 개의 낱자가 한 개의 소리로 나타나 기 때문에 자소-음소의 대응이 매우 규칙적이고 투명한(transparent) 언어이다. 반면에 영어는 표음문자이지만 한 개의 알파벳이 여 러 개의 음소로 나타나기 때문에 한글만큼 자소-음소 대응관계가 규칙적이지는 않다(Kim \& Cho, 2001). 이렇듯 한글의 각 자소는 일관적으로 대응되는 음소를 가지며, 한 음절 내(예: 가)에서는 대 체로 표기된 그대로 소리가 나타난다. 그러나 두 음절 이상이 되면 음운규칙에 의해서 음운변동(예: 각하[가카])이 일어난다(Choi, 2017). 이렇게 음운변동규칙이 적용되면서 영어에서와 같이 자소 와음소가 일치하지 않는 상황이 발생하기도 한다(Lim, 2006).

문자를 활용하여 읽기와 쓰기가 이루어지는 처리과정을 설명하 는 Ellis와 Young (1988)의 인지처리모델(cognitive processing model)을 살펴보면, 크게 두 가지 경로를 통하여 읽기와 쓰기처리가 이 루어지는데, 이는 어휘경로(lexical route)와 음운경로(phonological route)이다. 사람의 뇌 속에는 이미 학습을 통해 등록된 어휘들 의 목록인 철자어휘집(orthographic lexicon)이 있는데, 만약 제시 된 단어가 이미 저장되어 있는 단어라면 철자와 소리 일치 여부와 는 상관없이, 즉 규칙(일치)단어(regular word, 예: 이불)나 불규칙 (불일치)단어(irregular word, 예: 압력) 모두 어휘경로를 통해 처리
가 이루어진다. 이 경로가 손상되면 음운경로에 의존하여 읽기나 쓰기가 처리되기 때문에 자소와 음소가 1:1 대응되는 규칙단어와 비단어 자극에서는 문제가 없으나 자소와 음소 1:1 대응이 어려운 불규칙단어의 경우 어려움을 보인다. 흔히 관찰되는 오류로는 불 규칙단어를 제시하였을 때, 음운 경로의 자소-음소 변환을 통한 규 칙화(regularization) 읽기(예: 철자[철짜]->/철자/)이며(Na, 2016) 목표 단어의 발음에 따라 소리 나는 대로 쓰는 오류형태(phonological plausible errors)를 보이게 된다(Kim, 2012). 제시된 자극이 많이 접해보지 않은 생소한 비단어(nonword, 예: 건머)의 경우에는 철자어휘집을 사용할 수 없기 때문에 자소와 음소 간의 변환(grapheme-to-phoneme conversion)이 이루어지는 음운경로를 거쳐야 한다. 이 경로를 통해서는 자소-음소 대응이 1:1로 규칙적인 경우만 수행이 가능하므로 음운경로가 손상되면 어휘경로에 의존하여 수 행하기 때문에 철자어휘집에 있는 규칙단어와 불규칙단어의 읽기 와쓰기는 가능하지만 철자어휘집에 없는 비단어 읽기와 쓰기에는 어려움을 보인다. 흔히 관찰되는 오류로는 어휘경로의 철자어휘집 을 통한 어휘화(lexicalization) 오류이며, 음운삭제(phoneme deletion), 음운대치(phoneme replacement) 등 음운적인 조작을 필요 로 하는 이러한 여러 음운처리과제 수행에서 수행력이 저하된다 (Cho \& Pyun, 2015). 어휘경로와 음운경로 두 경로가 손상되면 의 미적 오류, 시각적 오류 등이 있으며 구체어에 비해 추상어에서 어 려움을 보인다(Yi, 1993a).

이렇듯 읽기와 쓰기에서 각 경로의 역할은 유사하지만 그 이외의 단계는 구분될 수 있다. 쓰기의 경우는 글자를 잠시 저장해두는 자 소-완충기(graphemic buffer)를 거쳐 글자 크기, 글자체, 자간 등을 결정하는 이서단계(allographic)로 가며, 다음 단계에서는 목표 글 자의 형태를 산출하기 위한 계획 및 프로그래밍이 이루어지고 마지 막 단계는 손을 이용하여 최종적으로 글자를 만들어 내는 운동집 행을 한다(Ellis \& Young, 1993). 더불어 읽기수행에 비해 쓰기수행 에서 수행력이 현저하게 저하되거나(Cho, Jung, \& Nam, 2002), 읽 기 또는 쓰기에서 선택적 결함을 보여주는 이중해리(double dissociation)현상이 보고되었다(Fayol, Zorman, \& Lt, 2009; Moll \& Landerl, 2009). 이러한 결과를 바탕으로 읽기와 쓰기는 서로 다른 경로 를 통하여 산출하게 되며 문어이해능력에 해당되는 읽기보다 문어 산출능력에 해당되는 쓰기가 더 복잡한 인지적 요구를 필요로 하 는 처리과정으로 알려져 있다(Park, 2013).

그동안 한국어에서 읽기 및 쓰기능력을 확인한 국내연구들(Kwon et al., 2002, 2005; Yim et al., 2008; Yun et al., 2009)은 주로 소수의 증례연구로 진행되었다. 전반성 실어증 환자 1-2명을 대상으로 한 증례연구(Cho et al., 2002; Cho, 2005)에서는 규칙단어, 불규칙단 
어, 비단어 조건에서 읽기 수행력을 확인하였다. 그리고 단어(규칙 단어, 불규칙단어)에 비해 비단어 수행력이 더 저하된 결과를 자 소-음소 변환(grapheme-to-phoneme conversion) 경로가 선택적 으로 손상되어 철자어휘집의 발음정보를 이용하는 어휘경로에 의 해서 읽기가 이루어졌기 때문으로 보았다. 이러한 결과로 인해 영어 의 음운실독증의 사례와 유사한 한글 음운실독증을 보고하였으 며 동시에 한글 단어읽기 시에도 이중경로가 사용된다는 입장을 지지하였다. 명칭 실어증 환자 3 명을 대상으로 고빈도와 저빈도에 해당하는 규칙단어와 불규칙단어 쓰기를 확인한 연구(Cho, 2005) 에서는 저빈도 불규칙단어에서 수행력이 가장 저하되는 결과를 토 대로 단어 빈도와 함께 규칙성에 따른 효과도 확인하였다. 이후 Cho와 Pyun (2015)은 뇌경색, 뇌졸중 및 외상성 뇌손상으로 인하 여 좌뇌 실비안열 주변(perisylvian)영역이 손상된 6명의 실어증 환 자를 대상으로 인지처리모델에 기반한 과제를 만들고 이에 근거하 여 음운실독증의 기제를 확인하고자 하였다. 저자들은 단어(규칙 단어, 불규칙단어)와 비단어 읽기과제와 더불어 한글 자모를 제시 하고 글자의 이름을 말하도록 하는 철자처리과제, 단어를 구성하 는 개개의 말소리를 분석, 변별, 조작할 수 있는지를 확인하는 음운 처리과제, 의미적으로 연관된 것을 찾는 의미처리과제를 사용하여 읽기능력을 평가하였다. 그 결과, 환자 대부분은 비단어 읽기와 음 운처리과제에서 수행력이 저하되었으나 철자와 의미처리과제의 수 행력이 상대적으로 높았으며 이를 통하여 한국 음운실독증 또한 해외의 연구들과 마찬가지로 좌측 실비안열의 병소와 관련이 있음 을 보고하였다. 최근에는 다수의 환자를 대상으로 한 선행연구 (Kim, 2017)에서는 실어증 환자 20명에게 규칙단어, 불규칙단어, 규칙비단어, 불규칙비단어 조건에서의 읽기 수행력을 확인하였다. 그 결과, 단어(규칙단어, 불규칙단어)에 비해 비단어(규칙비단어, 불규칙비단어)의 수행력이 낮았으며, 이를 통하여 실어증을 가장 잘 예측하는 변인은 단어 조건 중 규칙비단어의 수행력임을 보고 하면서 실어증과 실독증의 관련성을 고찰하였다.

이렇듯 그간의 국내에서 뇌졸중 환자를 대상으로 한 읽기와 쓰 기능력을 살펴본 연구들은 첫째, 소수의 연구를 제외하고는 주로 증례보고로 이루어져 그 결과를 일반화하는 데 어려움이 있다. 둘 째, 연구대상자 측면에서는 대부분의 연구에서 뇌졸중 집단 내에 뇌경색과 뇌출혈 대상자가 혼재되어 있었다. 뇌출혈과 뇌경색은 그 원인뿐만 아니라 보여지는 양상도 다소 이질적일 수 있으므로(Lee $\&$ Kim, 2011) 두 집단의 결과를 혼합하여 해석하는 것은 무리가 있 다. 셋째, 대상자의 문어체계를 전반적으로 확인하기 위해서는 읽 기와 쓰기를 함께 시행해야 하지만 이를 함께 살펴본 연구가 드물 다. 넷째, 그간의 연구들은 실어증을 보이는 환자만을 대상으로 하
였으므로 실어증 유무나 뇌손상 여부에 따른 문어장애의 특성을 확인할 수 없었다. 비록 좌반구 손상을 보일지라도 언어관련 영역이 침범되지 않은 경우에는 실어증이 동반되지 않을 수 있고(Kimura, 1977), 구어와 문어는 신경생리적 측면에서 관련 뇌영역이나 처리 과정이 일치하지 않을 수 있다(Rapp \& Caramazza, 1997, 2002). 또 한, 구어에 비하여 문어는 언어처리 과정과 더불어 계획화, 작업기 억과 같은 고차원적인 인지처리 과정이 요구된다(Olive \& Kellogg, 2002). 따라서 뇌손상으로 인한 인지능력의 변화로 인해 실어증이 없는 상태에서도 실독증과 실서증이 발생할 가능성이 있으므로 (Henry, Beeson, Stark, \& Rapcsak, 2007; Rapcsak \& Beeson, 2004) 실어증 유무에 따른 문어 수행력도 함께 확인할 필요가 있다.

본 연구에서는 좌반구 뇌경색 환자를 실어증을 보이는 환자와 실어증을 보이지 않는 환자로 나눈 후 음절의 수와 어휘성, 규칙성 등을 고려한 규칙단어, 불규칙단어, 규칙비단어 조건에서의 읽기 와 쓰기 특성 및 오류 양상을 확인하고자 하였다. 그리고 인지처리 모델(cognitive processing model)에 근거한 고찰을 통하여 추후 환 자의 예후를 판단하거나 중재의 방향을 수립하는 데 도움을 주고 자하였다.

\section{연구방법}

\section{연구대상}

본 연구는 만 20-90세에 해당하는 좌반구 뇌경색 환자 24명, 정 상성인(normal control, NC) 15명을 연구대상으로 하였다. 환자군 은 종합병원 신경과에 내원한 환자들로 구성되었으며, 세부 선정기 준은 다음과 같다. (1) 신경과 전문의로부터 좌반구 뇌경색으로 진 단받았으며, (2) 환자가 발병 전에 능숙한 읽기와 쓰기능력을 보유 하고 있어야 하므로 교육 정도가 초졸 학력 이상이며, (3) 오른손잡 이에 해당하여야 하며, (4) 과제 수행이 가능하도록 적어도 한 손은 마비가 없는 환자를 대상으로 하였다. 정상 성인의 선정기준은 다 음과 같다. (1) 건강선별설문지(Christensen Multhaup, Nordstrom, \& Voss, 1991)를 실시하여 뇌손상이나 정신적 질환 및 말-언어장애 병력이 없으며, (2) 한국판 간이정신상태검사(Korean-Mini Mental State Examination, K-MMSE; Kang, Na \& Hahn, 1997)를 실시하 여 그 수행력이 학력과 연령을 고려하였을 때 정상범위의 인지기능 내에 포함되는 경우, (3) 과제 수행이 가능하도록 시력과 청력이 정 상인 경우, (4) 과제 특성상 능숙한 읽기와 쓰기능력을 보유하여야 하므로 교육 정도가 초졸 학력 이상인 경우, (5) 오른손잡이에 해당 하며, (6) 단축형 노인우울척도(Short form Geriatric Depression Scale, SGDS; Kee, 1996)를 실시하여 8점 이하로 우울감이 없는 성 
Table 1. Participants' characteristics ( $N=24)$

\begin{tabular}{lccc}
\hline & Aphasia+ $(\mathrm{N}=13)$ & Aphasia- $(\mathrm{N}=11)$ & $\mathrm{NC}(\mathrm{N}=15)$ \\
\hline Age (yr) & $69.38 \pm 12.49$ & $58.27 \pm 20.25$ & $57.87 \pm 16.33$ \\
Education (yr) & $8.77 \pm 3.37$ & $11.09 \pm 3.36$ & $11.27 \pm 4.04$ \\
Aphasia quotient & $70.88 \pm 19.71$ & $96.25 \pm 2.53$ & - \\
Lesion & & & \\
Cortical & 10 & 4 & - \\
Subcortical & 3 & 7 & - \\
\hline
\end{tabular}

Values are presented as mean \pm SD.

Aphasia+=aphasic patient; Aphasia- = non-aphasic patient; NC=normal control. ${ }^{*} p<.05$.

인을 대상으로 하였다. 연구문제에 따른 수행력 비교를 위하여 환 자 집단의 경우 실어증이 있는 환자(aphasia+)와 실어증이 없는 환 자(aphasia-)로 나누었다. 세 집단의 연령 $\left(F_{(2,36)}=2.071, p=.141\right)$ 및 교육년수 $\left(F_{(2,36)}=1.923, p=.161\right)$ 와 환자 집단 간 연령 $(t=1.646)$ 및 교육년수 $(t=-1.684)$ 는 통계적으로 유의한 차이가 없었다. 대상자 의 배경정보는 Table 1과 Appendix 1에 제시하였다.

\section{자료수집 도구}

본 연구과제의 앞서 뇌경색 환자에게 실어증의 중증도를 확인할 수 있는 한국판 웨스턴실어증검사(Paradise-Korean Western Aphasia Battery-Revised, PK-WAB-R; Kim \& Na, 2012)를 실시하고 실 어증 지수(aphasia quotient, $\mathrm{AQ}$ )를 산출하여 실어증 환자와 실어 증 없는 환자로 구분하였다. 그 후 대상자들의 단어 읽기와 쓰기 수 행력을 살펴보기 위해 기존에 개발된 검사도구(PK-WAB-R, KOL$\mathrm{RA}$ )의 읽기, 쓰기항목에서 사용된 단어들과 겹치지 않도록 단어 를 자체적으로 선정하여 실시하였다. 단어목록 제작 시, 자소와 음 소 $1: 1$ 대응되는 규칙단어(예: '이불'), 자소와 음소 $1: 1$ 대응되지 않 는 불규칙단어(예: '각하[가카]'), 자소와 음소 $1: 1$ 대응되는 비단어 (예. 도누)로 구성하였다. 먼저, 규칙단어와 불규칙단어 선정 기준은 “현대 국어 사용 빈도 조사2” (National Institute of Korean Language, 2005)를 참조하였다. 보고된 총 82,501개의 일반어휘 통계 중 빈도순으로 정렬한 후 상위 $30 \%$ 에 해당하는 것을 고빈도 단어, 하위 $30 \%$ 에 해당하는 것을 저빈도 단어로 구분하였다. 그 후 다양 한 음소가 포함되면서 단어 조건(규칙, 불규칙) 간 고빈도와 저빈도 단어의 비율이 같게 포함되도록 하여 총 70 개(읽기 40 개, 쓰기 30 개)를 선정하였다. 또한 음절길이가 길어지는 경우 작업기억능력 등에 영향을 받을 수 있으므로(Gathercole, Willis, Baddeley, \& Emslie, 1994; Nam et al., 1997) 모든 단어는 3음절의 이하로 구성 하였으며, 각 단어 조건마다 포함된 단어의 음절 개수를 통일하였 다. 단, 읽기의 경우 1 음절은 비단어로 오인될 가능성이 있으므로
2-3음절로 구성하였다. 불규칙단어의 음운변동은 우리말 단어의 음운변동 비율에 대한 선행연구(Cho, 2000; National Institute of Korean Language, 2003; Shin \& Cha, 2003)를 참고하여 선정하였 다. 선행연구에서 보고된 총 10 개의 음운변동 중 읽기에서는 6 개의 음운변동(경음화, 비음화, 유음화, 기식음화, 구개음화, 자음군단순 화)을 선정하였다. 이때, 나머지 4개(연음화, 할락, 사잇소리, 평폐 쇄음화)의 음운변동 중 연음화의 경우 환자가 단어를 보고 읽을 때 연음화 규칙을 적용하지 않고 한 음절씩 읽는 경향을(Kim, 2012) 보일 수 있으므로 제외하였다. 할ㄹ락은 빈도가 낮으며 활용이므 로 제외시켰으며, 사잇소리 현상은 빈도가 낮으며 정상 성인도 음운 변동을 적용하지 않는 경향이 있어(Kim \& Pae, 2011) 제외하였다. 평폐쇄음화('밖’ $\rightarrow$ '박], '부억’ $\rightarrow[$ 부엌])는 읽는 방법에 다른 대안이 없기 때문에(Lim, 2006) 제외하였다. 쓰기에서는 7개의 음운변동 (경음화, 비음화, 유음화, 기식음화, 구개음화, 평폐쇄음화, 자음군 단순화)을 선정하였다. 읽기에서 제외한 평폐쇄음화는 쓰기에서 오류가 나타날 시 확연하게 보이기 때문에 선정하였다. 나머지 3 개 의 음운변동(연음화, 할락, 사잇소리 현상)은 읽기와같은 이유로 제외하였다. 비단어는 한글에 존재하지 않으며 단어 자체에 의미가 없는 것을 말한다. 이때, 비단어의 경우에는 규칙단어, 불규칙단어 와 같이 음절수를 통일하였으며 각 범주당 음절의 개수도 통일하 였다. 이러한 선정기준에 따라 읽기과제는 규칙단어 20개, 불규칙 단어 20 개, 비단어 20 개로 총 60 개의 문항으로 구성되었으며, 쓰기 과제는 규칙단어 15 개, 불규칙단어 15 개, 비단어 15 개로 총 45 개의 문항으로 구성되었다(Appendix 2).

\section{자료수집 절차}

본 연구에서는 먼저 과제 시행 전 대상자의 적합성 및 기초 자료, 연구에 대한 동의와 설명을 진행하였다. 선별검사로는 뇌경색 환자 에게 실어증의 중증도를 확인할 수 있는 한국판 웨스턴실어증검사 (PK-WAB-R; Kim \& Na, 2012)를 실시하였으며, 본 연구의 적합하 지 않은 대상자는 제외하였다. 그 후 대상자에게 연구자가 자체적 으로 제작한 읽기, 쓰기과제를 실시하였다. 검사는 조용한 공간에 서 검사자와 대상자가 1:1로 진행하였다. 과제는 1 음절 이상 3 음절 이하(읽기의 경우 2 음절이상 3 음절 이하)의 규칙단어, 불규칙단어, 비단어로 나누어 실시하였다. 이때, 절차는 학습효과(learning ef$\mathrm{fect}$ 를 최소화하기 위해 먼저 쓰기를 실시하고 그 다음에 읽기를 실시하였다. 쓰기 과제 시 검사자가 “이제부터 쓰기 과제를 시작하 겠습니다. 제가 불러드리는 단어를 듣고 따라 말하신 후에 종이에 써주세요.”라고 요청하고 쓰기를 진행하였다. 단어당 한 번만 제시 하는 것을 원칙으로 하되 따라말하기 등을 활용하여 틀리게 따라 
말하거나 환자가 요청하는 경우 다시 제시하였다. 그래도 알아듣지 못할 시 의미단서(예: / 덫/->'짐승을 꾀어 잡는 기구') 혹은 예문(예: /몫/->'몫을 나누다')을 들려주고 쓰도록 하였다. 대상자 중 손의 마비가 있는 경우를 고려하여 충분한 시간을 가지고 쓰기를 진행 할 수 있도록 하였다. 쓰기 과제 총 3세트가 끝나면 대상자의 집중 력이 떨어질 경우를 고려해 읽기과제 시작 전 2-3분의 휴식시간을 취하게 한 후 읽기과제를 실시하였다. 쓰기 과제 후 "이제는 읽기 과 제를 시작하겠습니다. 제가 보여드리는 단어 카드를 보고 소리 내 어 읽어주세요.”라고 요청하고 목표 단어를 하나씩 제시하였다. 읽 기 과제 시 규칙단어, 불규칙단어, 비단어 총 3세트로 제작하였다. 대상자가 쓰기와 읽기과제 중 못하겠다는 의사표시를 할 경우와 20 초 이상 반응이 없을 때 기록지에 NR (무반응)로 표시하고 다음 단어를 제시하였다. 대상자가 과제 시 자가 수정을 할 경우에는 최 종 반응으로 기록하고 채점하였다. 읽기과제 시 대상자의 반응을 음성으로 녹음하였으며, 그 후 검사자가 녹음 파일을 듣고 정/오반 응 여부를 기록하였다. 쓰기과제 시 환자가 마비가 있는 경우 방향 성 등 영향을 미치는 것을 고려해 자소가 맞으면 형태와 상관없이 현장에서 검사자가 바로 기록지에 정/오반응 여부를 기록하였다. 총 검사 평균 소요시간은 40-50분이었다. 본 연구의 모든 절차는 한림대학교 춘천성심병원 생명윤리연구위원회(No. 2017-20)의 승 인을 받았다.

\section{자료분석}

본 연구에서는 실어증 환자군과 실어증 없는 환자군, 정상군의 정/오반응 수와 오류양상을 측정하였다. 먼저 읽기 오류 분석은 음 성으로 녹음된 파일을 가지고 대상자의 반응을 전사하였으며, 정 반응은 1 점, 오반응은 0 점으로 채점하였다. 총 점수는 60 점으로, 각 범주당 최고 점수는 20 이었다. 구체적인 오류 양상과 빈도를 알아 보고자 오류분석을 실시하였다. 읽기 오류분석의 기준은 선행연 구(Hwang, Kim, Cho, \& Yoon, 2017; Kim, 2002; Platel et al., 1993; Sung, 2010)를 참고하여 필요한 오류분석 항목을 본 연구목적에 맞게 수정, 보완하여 사용하였다. 오류유형은 규칙단어, 불규칙단 어, 비단어로 나누어 진행하였다(Appendix 3). 쓰기과제 분석은 종 이에 적힌 단어를 검사자가 하나씩 확인하여 정반응은 1 점, 오반응 은 0 점으로 채점하였다. 총점수는 45 점으로, 각 범주당 최고 점수 는 15이었다. 쓰기오류 분석기준은 선행연구(Kim, 2002; Platel et al., 1993; Sung, 2010)를 참고하여 필요한 오류분석 항목을 본 연구 목적에 맞게 수정, 보완하여 사용하였다. 오류유형은 규칙단어, 불 규칙단어, 비단어로 나누어 진행하였다(Appendix 4).

\section{신뢰도}

본 연구의 읽기와쓰기 오류유형에 대한 신뢰도를 검증하기 위해 평가자 간 채점 일치율을 산출하였다. 연구자가 평가 및 채점을 진 행하였으며 대상자의 $20 \%$ 에 해당하는 자료를 무작위로 추출하여 검사자 간 신뢰도를 분석하였다. 이를 위해 언어병리학을 전공하고 있는 대학원생 1 명에게 녹음된 파일을 듣고 전사 및 채점을 진행하 도록 하였다. 또한 미리 오류유형 분류기준에 대한 지침을 제공하 였으며, 오반응을 오류유형에 따라 분석하도록 하였다. 읽기 오류 유형에 대한 일치율은 97.5\%였으며, 쓰기 오류유형에 대한 일치율 은 $95.4 \%$ 였다.

\section{통계 분석}

본 연구를 통해 수집된 자료의 통계 처리는 SPSS version 23 통계 프로그램을 활용하였다. 세 집단(실어증 환자군, 실어증 없는 환자 군, 정상군)의 단어조건에 따른 수행력 비교를 하기 위해 집단과 단 어조건을 고려한 혼합설계 분산분석(mixed design ANOVA)을 실 시하였다. 그 후 유의한 차이를 보이는 집단에 대해 알아보기 위해 Bonferroni 사후검정을 적용한 대응별 비교분석(pairwise comparison with Bonferroni correction)을 실시하였다. 추가적으로 집단 별로 단어조건 간 차이를 확인하기 위해서는 반복측정분산분석 (repeated ANOVA)을 실시한 후 검증한 횟수만큼 유의확률을 낮 추는 본페로니 교정(Bonferroni correction)을 시행하였다. 오류유 형의 경우에는 환자들이 주로 보이는 쓰기장애 유형을 분석하기 위해 오류유형에 대한 질적 분석을 실시하였다. 각 집단의 오반응을 해당 오류유형으로 분류하여 총계를 내고, 해당 오류유형의 개수 를 전체 오류 개수로 나누고 100 을 곱하여 백분율을 계산하였다.

\section{연구결과}

\section{실어증 환자군과 실어증 없는 환자군, 정상군의 읽기와 쓰기과제 수행능력 비교}

세 집단 간 읽기 정반응 점수 비교

집단 및 단어조건별 정반응 점수에 대한 기술통계량은 Table 2 와 같다. 혼합설계 분산분석 결과, Mauchly의 구형성 검정에서 구 형성이 성립되지 않았다 $(W=.614, p<.001)$. 구형성 가정이 성립되 지 않았으므로 Greenhouse-Geisser의 $F$ 값을 기초로 해석하였다. 그 결과, 집단에 따른 주효과 $\left(F_{(2,36)}=6.509, p=.004\right)$ 와 단어조건에 따른 주효과 $\left(F_{(1.443,51.935)}=33.254, p<.001\right)$ 가 나타났으며, 또한 집단 과 단어조건 간에 상호작용이 있는 것으로 나타났다 $\left(F_{(2.885,51.935)}=\right.$ $5.501, p=.003)$. 상호작용 효과에 대한 분석으로 Bonferroni 검정 
Table 2. Word reading by groups

\begin{tabular}{lccccc}
\hline & Aphasia+ $(\mathrm{N}=13)$ & Aphasia- $(\mathrm{N}=11)$ & $\mathrm{NC}(\mathrm{N}=15)$ & $F$ & $p$ \\
\hline Regular word & $17.62 \pm 5.62$ & $19.91 \pm .30$ & $20.00 \pm .00$ & 2.262 & - \\
Irregular word & $14.62 \pm 6.17$ & $18.73 \pm 1.35$ & $18.80 \pm 1.52$ & $5.303^{*}$ & $\begin{array}{c}\text { Aphasia+, Aphasia- }{ }^{*} \\
\text { Aphasia+, NC }\end{array}$ \\
Nonword & $11.46 \pm 7.25$ & $17.55 \pm 1.97$ & $18.20 \pm 1.57$ & $9.317^{* * *}$ & Aphasia+, Aphasia- $^{* *}$ \\
\hline
\end{tabular}

Values are presented as mean \pm SD.

Aphasia $+=$ aphasic patient; Aphasia- $=$ non-aphasic patient; $\mathrm{NC}=$ normal control .

${ }^{*} p<.05,{ }^{* *} p<.01,{ }^{* * *} p<.001$.

Table 3. Word writing by groups

\begin{tabular}{|c|c|c|c|c|c|}
\hline & Aphasia $+(N=13)$ & Aphasia- $(\mathrm{N}=11)$ & $N C(N=15)$ & $F$ & $p$ \\
\hline Regular word & $7.15 \pm 5.66$ & $13.55 \pm 1.75$ & $14.20 \pm 1.21$ & $16.552^{* * *}$ & $\begin{array}{l}\text { Aphasia+, Aphasia-*** } \\
\text { Aphasia+, NC }{ }^{* * *}\end{array}$ \\
\hline Irregular word & $4.46 \pm 5.19$ & $9.55 \pm 4.48$ & $10.27 \pm 3.99$ & $6.398^{* *}$ & $\begin{array}{l}\text { Aphasia+, Aphasia-* } \\
\text { Aphasia+, NC }{ }^{* *}\end{array}$ \\
\hline Nonword & $3.62 \pm 3.93$ & $8.55 \pm 3.36$ & $12.53 \pm 1.77$ & $29.200 * * *$ & $\begin{array}{c}\text { Aphasia+, Aphasia-** } \\
\text { Aphasia+, } \mathrm{NC}^{* * *} \\
\text { Aphasia-, NC**}\end{array}$ \\
\hline
\end{tabular}

Values are presented as mean \pm SD.

Aphasia+=aphasic patient; Aphasia- =non-aphasic patient; $\mathrm{NC}=$ normal control.

${ }^{*} p<.05,{ }^{* *} p<.01,{ }^{* * *} p<.001$.

을 적용하여 대응별 비교분석(pairwise comparison with Bonferroni correction)을 실시한 결과, 불규칙단어에서 실어증 환자군은 실어증 없는 환자군 $(p=.034)$, 정상군 $(p=.017)$ 보다 수행력이 유의 하게 낮았으며, 비단어에서도 실어증 없는 환자군 $(p=.006)$, 정상 군 $(p=.001)$ 보다 수행력이 유의하게 낮았다. 단어조건의 주효과가 나타나 단어조건 간 비교한 결과, 비단어에 비해 규칙단어 $\left(F_{(1,36)}=\right.$ $40.995, p<.001)$, 불규칙단어 $\left(F_{(1,36)}=6.719, p<.001\right)$ 의 평균점수가 높게 나타났다.

집단 내 단어조건 간 차이를 살펴본 결과, 실어증 환자군은 규칙 단어에 비해 불규칙단어 $(t=-3.000, p<.001)$, 비단어 $(t=-6.154$, $p<.001)$ 의 수행력이 유의하게 낮았으며, 불규칙단어에 비해 비단 어 $(t=-3.154, p<.001)$ 수행력이 유의하게 낮았다. 실어증 없는 환 자군과 정상군은 규칙단어, 불규칙단어, 비단어 간 유의한 차이가 없었다 $(p>.05)$.

\section{세 집단 간 쓰기과제 정반응 점수 비교}

집단 및 단어조건별 정반응 점수에 대한 기술통계량은 Table 3과 같다. 혼합설계 분산분석 결과, 집단에 따른 주효과 $\left(F_{(2,36)}=16.953\right.$, $p<.001)$ 와 단어 조건에 따른 주효과 $\left(F_{(2,72)}=38.030, p<.001\right)$ 가 나 타났으며, 또한 집단과 단어조건 간에 상호작용이 있는 것으로 나타 났다 $\left(F_{(4,72)}=3.695, p=.009\right)$. 상호작용 효과에 대한 분석으로서 Bon- ferroni 검정을 적용하여 대응별 비교분석(pairwise comparison with Bonferroni correction)을 실시한 결과, 규칙단어에서 실어증 환자군은 실어증 없는 환자군 $(p<.001)$, 정상군 $(p<.001)$ 보다 수행 력이 유의하게 낮았으며, 불규칙단어에서도 실어증 없는 환자군 $(p=.030)$, 정상군 $(p=.006)$ 보다 수행력이 유의하게 낮았고, 비단어 에서도 실어증 없는 환자군 $(p=.001)$, 정상군 $(p<.001)$ 보다 수행력 이 유의하게 낮았다. 실어증 없는 환자군은 정상군에 비해 규칙단어 ( $p>$ >05)와 불규칙단어 $(p>.05)$ 에서는 유의한 차이가 없었으나 비단 어에서 정상군 $(p=.007)$ 보다 수행력이 유의하게 낮았다. 단어조건 의 주효과가 나타나 단어조건 간 비교한 결과, 비단어에 비해 규칙 단어 $\left(F_{(1,36)}=74.515, p<.001\right)$ 의 평균점수가 높았으나, 비단어에 비해 불규칙단어 $\left(F_{(1,36)}=.093, p=.762\right)$ 는 유의한차이가 나타나지 않았다.

집단 내 단어조건 간 차이를 살펴본 결과, 실어증 환자군은 규칙 단어에 비해 불규칙단어 $(t=-2.692, p=.014)$, 비단어 $(t=-3.538, p<$ .001)의 수행력이 유의하게 낮았으며, 불규칙단어와 비단어 간 유 의한 차이는 나타나지 않았다 $(t=-.846, p>.05)$. 실어증 없는 환자 군은 규칙단어에 비해 불규칙단어 $(t=-4.000, p=.001)$, 비단어 $(t=$ $-5.000, p<.001)$ 의 수행력이 유의하게 낮았으며, 불규칙단어와 비 단어 간 차이는 없었다 $(t=-1.000, p=.752)$. 정상군은 규칙단어 $(t=-3.933, p<.001)$ 나 비단어 $(t=-2.267, p=.012)$ 에 비해 불규칙단 어의 수행력이 유의하게 낮았다. 


\section{집단 내 오류유형별 비율}

집단 내 오류유형을 살펴보기 위해 오류분석을 진행하였으며, 규칙단어, 불규칙단어, 비단어로 나눠서 각 단어조건에 따른 차이 를 확인하였다.

\section{읽기 오류유형 특성}

각 집단별 오류유형을 살펴보기 위해 규칙단어, 불규칙단어, 비 단어로 나눠서 오류분석을 진행하였다. 환자들이 주로 보이는 쓰 기장애 유형을 분석하기 위해 오류유형에 대한 질적 분석을 실시 하였다. 먼저, 실어증 환자군, 실어증 없는 환자군, 정상군이 규칙단 어, 불규칙단어, 비단어에서 나타낸 오류유형을 살펴보면 다음과 같다(Table 4). 오류유형별로 살펴보면 규칙단어에서 실어증 환자 군은 음운형태오류가 $63.64 \%$ 로 가장 높았으며, 실어증 없는 환자 군 또한 음운형태오류가 높게 나타났다. 불규칙단어에서는 실어증 환자군은 음운형태오류가 $57.14 \%$ 로 가장 높았으며, 그 다음으로 분류불가 $26.53 \%$ 로 높게 나타났다. 실어증 없는 환자군은 음운형 태오류가 $64.29 \%$ 로 가장 높았으며, 그 다음으로 규칙화 $35.71 \%$ 로 높게 나타났다. 정상군 또한 음운형태오류(56.25\%), 규칙화(43.75\%) 순으로 나타났다. 비단어에서는 실어증 환자군은 음운형태오류가

Table 4. The number of errors according to reading error types

\begin{tabular}{lccc}
\hline Error type & $\begin{array}{c}\text { Aphasiat } \\
(\mathrm{N}=13)\end{array}$ & $\begin{array}{c}\text { Aphasia- } \\
(\mathrm{N}=11)\end{array}$ & $\begin{array}{c}\mathrm{NC} \\
(\mathrm{N}=15)\end{array}$ \\
\hline Regular word & & & \\
Phonologically implausible error & $7(63.64)$ & $1(100)$ & $0(0)$ \\
Nonclassifiable (neologism) & $4(36.36)$ & $0(0)$ & $0(0)$ \\
DK & $0(0)$ & $0(0)$ & $0(0)$ \\
NR & $0(0)$ & $0(0)$ & $0(0)$ \\
SUM & 11 & 1 & 0 \\
Irregular word & & & \\
Phonologically implausible error & $28(57.14)$ & $9(64.29)$ & $9(56.25)$ \\
Regularization & $5(10.20)$ & $5(35.71)$ & $7(43.75)$ \\
Nonclassifiable (neologism) & $13(26.53)$ & $0(0)$ & $0(0)$ \\
DK & $3(6.12)$ & $0(0)$ & $0(0)$ \\
NR & $0(0)$ & $0(0)$ & $0(0)$ \\
SUM & 49 & 14 & 16 \\
Nonword & & & \\
Phonologically implausible error & $47(52.22)$ & $26(96.30)$ & $26(96.30)$ \\
Lexicalization & $19(21.11)$ & $1(3.70)$ & $0(0)$ \\
Nonclassifiable (neologism) & $17(18.89)$ & $0(0)$ & $1(3.70)$ \\
DK & $7(7.78)$ & $0(0)$ & $0(0)$ \\
NR & $0(0)$ & $0(0)$ & $0(0)$ \\
SUM & 90 & 27 & 27 \\
\hline
\end{tabular}

Values are presented as number (\%).

Aphasia+=aphasic patient; Aphasia-=non-aphasic patient; NC=normal control; $\mathrm{DK}=$ don't know; $\mathrm{NR}=$ no response.
$52.22 \%$ 로 높게 나타났으며, 그 다음으로 어휘화(21.11\%)가 높게 나 타났다. 실어증 없는 환자군, 정상군 또한 음운형태오류가 $96.30 \%$ 로 가장 높게 나타났다.

\section{쓰기 오류유형 특성}

각 집단별 오류유형을 살펴보기 위해 규칙단어, 불규칙단어, 비 단어로 나눠서 오류분석을 진행하였다. 먼저, 실어증 환자군, 실어 증 없는 환자군, 정상군이 규칙단어, 불규칙단어, 비단어에서 나타 낸 오류유형을 살펴보면 다음과 같다(Table 5). 오류유형별로 살펴 보면 규칙단어에서 실어증 환자군은 음운형태오류가 $81.08 \%$ 로 가 장 높았으며, 그 다음으로 분류불가(18.92\%)가 높게 나타났다. 실어 증 없는 환자군은 음운형태오류가 $68.75 \%$ 로 높게 나타났다. 정상 군 또한 음운형태오류가 $84.62 \%$ 로 가장 높게 나타났다. 불규칙단 어에서는 실어증 환자군은 음운형태오류가 $45.45 \%$ 로 가장 높았으 며, 그 다음으로 소리 나는 대로 쓴 오류가 28.79\%로 높게 나타났 다. 실어증 없는 환자군은 소리 나는 대로 쓴 오류가 $51.67 \%$ 로 가장 높았으며, 그 다음으로 음운형태오류 $35.00 \%$ 로 높게 나타났다. 정

Table 5. The number of errors according to writing error types

\begin{tabular}{lccc}
\hline Error type & $\begin{array}{c}\text { Aphasia+ } \\
(\mathrm{N}=13)\end{array}$ & $\begin{array}{c}\text { Aphasia- } \\
(\mathrm{N}=11)\end{array}$ & $\begin{array}{c}\mathrm{NC} \\
(\mathrm{N}=15)\end{array}$ \\
\hline Regular word & & & \\
Phonologically plausible error & $30(81.08)$ & $11(68.75)$ & $11(84.62)$ \\
Phonologically implausible error & $7(18.92)$ & $5(31.25)$ & $2(15.38)$ \\
Nonclassifiable (neologism) & $0(0)$ & $0(0)$ & $0(0)$ \\
DK & $0(0)$ & $0(0)$ & $0(0)$ \\
NR & $0(0)$ & $0(0)$ & $0(0)$ \\
SUM & 37 & 16 & 13 \\
Irregular word & & & \\
Phonologically plausible error & $19(28.79)$ & $31(51.67)$ & $44(63.77)$ \\
Phonologically implausible error & $30(45.45)$ & $21(35.00)$ & $21(30.43)$ \\
Nonclassifiable (neologism) & $14(21.21)$ & $8(13.33)$ & $4(5.80)$ \\
DK & $3(4.55)$ & $0(0)$ & $0(0)$ \\
NR & $0(0)$ & $0(0)$ & $0(0)$ \\
SUM & 66 & 60 & 69 \\
Nonword & & & \\
Phonologically plausible error & $1(1.14)$ & $0(0)$ & $0(0)$ \\
Phonologically implausible error & $46(52.27)$ & $45(63.38)$ & $29(78.38)$ \\
Lexicalization & $15(17.05)$ & $22(30.99)$ & $4(10.81)$ \\
Nonclassifiable (neologism) & $14(15.91)$ & $4(5.63)$ & $2(5.41)$ \\
DK & $1(1.14)$ & $0(0)$ & $2(5.41)$ \\
NR & $11(12.50)$ & $0(0)$ & $0(0)$ \\
SUM & 88 & 71 & 37 \\
\hline & & & \\
\hline
\end{tabular}

Values are presented as number (\%).

Aphasia+=aphasic patient; Aphasia-=non-aphasic patient; NC=normal control; $\mathrm{DK}=$ don't know; $\mathrm{NR}=$ no response. 
상군 또한 소리 나는 대로 쓴 오류가 $63.77 \%$ 로 가장 높았다. 비단어 에서는 실어증 환자군은 음운형태오류가 $52.27 \%$ 로 높게 나타났으 며, 그 다음으로 어휘화(17.05\%)가 높게 나타났다. 실어증 없는 환 자군 63.38\%로 음운형태오류가 가장 높게 나타났으며, 정상군 또 한 $78.38 \%$ 로 음운형태오류가 가장 높게 나타났다.

\section{논의 및 결론}

실어증 유무에 따라 뇌경색 집단을 나눈 후에 세 집단(실어증 환 자군, 실어증 없는 환자군, 정상군) 간 읽기와 쓰기 수행력을 비교 한 결과, 실어증 환자군이 실어증 없는 환자군, 정상군에 비해 두 과 제 모두에서 전반적으로 수행력이 낮았다. 이러한 결과는 발병 후 좌반구 언어중추의 손상으로 실어증을 보이면서(Hanlon, Lux, \& Dromerick, 1999) 동시에 전반적인 문어능력에 어려움을 겪는다는 선행연구와 일치한다(Nadeau et al., 2000; Patterson \& Marcel, 1977; Rosenbeck, LaPointe, \& Wertz, 1989; Ha et al., 2013). 구어능력은 생각을 단어나 문장으로 나타내 타인과 의사소통을 하기 위해 사 용하는 언어 행위이며(Jung, 1993), 문어능력은 글을 읽고 쓰는 기 술(Moon, 2001)로서 구어능력과 문어능력은 메시지를 전달하는 수단에 따라 구별되지만 두 처리과정의 의미, 음운, 어휘, 철자 지식 단계는 서로 밀접한 관련이 있다(Ha et al., 2013; Heo, Kwag \& Lee, 2011; Piras \& Marangolo, 2004)는 측면으로 본 연구결과를 해석할 수 있다.

단어조건에 따른 집단 간 수행력을 비교한 결과, 실어증 있는 환 자군은 실어증 없는 환자군, 정상군에 비하여 읽기에서는 불규칙 단어와 비단어에서, 쓰기에서는 규칙단어, 불규칙단어, 비단어에 서 수행력이 낮았다. 먼저, 실어증 환자군에서 읽기와 쓰기 모두 불 규칙단어의 수행력이 저하되었음을 보여주는 결과는 실어증 환자 를 대상으로 한 선행연구(Cho, 2005)에서 규칙단어보다 불규칙단 어에서 더 수행력이 낮게 나타난 결과와 일치한다. 규칙단어와 불 규칙단어는 이미 알고 있는 친숙한 단어일 경우 어휘경로를 통해 처리가 이루어진다. 이때 규칙단어 읽기, 쓰기는 불규칙단어 읽기, 쓰기에 비하여 1:1로 자소-음소의 대응이 이루어지므로(Yi, 1993b) 어휘-의미 표상을 형성할 시 많은 부담을 주지 않은 반면, 음운변동 이 포함된 불규칙단어의 경우 그 처리부담이 가중되면서(Cho \& $\mathrm{Nam}, 2002)$ 규칙단어에 비해 억제, 주의집중 등 인지적으로 처리해 야 되는 과정이 더 많이 요구될 가능성이 있다(Hwang et al., 2017; Yoon \& Lee, 2014). 그러므로 실어증 환자는 언어중추의 손상과 인 지기능의 손상(Helm-Estabrooks, 2002; Marinelli, Spaccavento, Craca, Marangolo, \& Angelelli, 2017)으로 인해 처리부담이 가중
되면서 불규칙단어 조건에서 더욱 어려움을 겪는 것으로 생각해 볼 수 있겠다. 비단어의 경우에도 읽기와 쓰기과제 모두에서 실어 증 환자군이 실어증 없는 환자군, 정상군보다 수행력이 저하되었으 며, 특히 3 가지 단어 조건(규칙단어, 불규칙단어, 비단어) 중 비단어 의 수행력이 가장 저하되었다. 이는 실어증 환자군에서 단어(규칙 단어, 불규칙단어)보다 비단어 읽기의 수행력이 낮았던 선행연구 (Cho \& Pyun, 2015; Kim, 2017)결과와 일치한다. 비단어는 처음 보 는 단어이면서 낮선 단어이므로 내부철자집에 의미가 저장되어 있 지 않아음운자극을 철자로 1:1로 변환하는 과정(Kim \& Pae, 2011) 즉, 음운경로를 통해서 처리가 이루어져야 한다. 정상 성인의 경우 에는 읽기와 쓰기 시 단어의 의미와 철자정보 등 모든 정보처리단 계들이 정상기능을 하므로(Cho \& Pyun, 2015) 비단어를 내부철자 집 내의 의미와 연결할 수 없을 때는 자소-음소 변환(grapheme-tophoneme conversion)과정을 통해서 어려움 없이 읽거나 쓸 수 있 다. 그러나 음소를 자소로 변환하는 음운경로(phonological route) 에 손상이 있다면(Henry et al., 2007) 비단어의 읽기와 쓰기가 어려 워질 수 있다. 이를 뇌신경학적 위치와 관련 지어 보면, 영어권의 환 자 연구들에서 음운실독 및 실서증(phonological agraphia)이 자 주 보고되는 뇌손상 영역은 실비안열 주변(perisylvian) 영역이었 다(Langmore \& Canter, 1983; Roeltgen \& Heilman, 1984; Shallice, 1981). 선행연구(Cho \& Pyun, 2015)의 음운실독증 환자들은 모두 실비안열 주변 영역의 손상을 포함하고 있었다. 이에 본 연구의 실어 증 환자 13 명의 뇌영상 판독 자료를 확인한 결과 공통적으로 좌측 실비안열과 그 내측에 위치한 뇌섬(insula), 방사관(corona radiate) 및 기저핵(basal ganglia)에 병소가 있는 것이 확인되었으며, 선행연 구(Cho \& Pyun, 2015)의 실어증 환자들의 AQ가 52.3이었던 것과 비교하여 본 연구의 실어증 환자의 $\mathrm{AQ}$ 는 70.88 로 상대적으로 높았 음에도 불구하고 비단어의 수행력이 저하된 결과는 음운경로의 처 리과정과 관련된 병소의 영향이 반영된 것으로 해석할 수 있겠다.

보다 흥미로운 점은 $\mathrm{AQ}$ 평균이 96.25점이었던 실어증이 없는 환 자군이 비단어 쓰기에서 정상군에 비해 수행력 저하를 보인 것이 다. 먼저 인지처리모델(cognitive processing model)에 기반하여 살 펴보자면 이러한 결과는 구어와 문어의 처리과정이 독립적이며 각 각의 어휘집(lexicon)이 존재한다는 가설을 뒷받침한다(Chapey, 2008). 선행연구(Ha et al., 2013)에서는 뇌손상 환자를 대상으로 그 림을 보고 구두로 설명하는 과제와 쓰기로 설명하는 과제 간의 수 행력을 비교하여 구어와 문어의 처리과정이 독립적으로 이루어지 는가를 살펴보았다. 그리고 구어와 문어 수행력 간에 유의한 차이 가 나타난 결과를 통해 구어와 문어 간의 수행력의 차이는 서로 공 유되는 부분이 있으나 두 처리과정이 동일하지 않을 가능성(Chen, 
Cai, \& Gong, 2004; Sakurai, Asami, \& Mannen, 2010)을 주장하였 으며, 철자독립성가설(orthographic autonomy hypothesis)을 지지 하였다. 일반적으로 언어에서 음운을 처리하는 능력은 문어의 자 소와 구어의 음소처리에 모두 관여할 수 있다. 그러나 음소와 음소 간의 변환이 아닌 음소와 자소 간의 변환 단계에서 손상이 있다면 구어능력과는 별개로 문어능력이 선택적으로 저하될 수 있을 것이 다. 여기서 추가적으로 논의할 것은, 문어능력 내에서도 읽기과제 에서는 정상군과 차이가 없었으나 쓰기과제에서만 정상군에 비하 여 저하된 수행력을 보인 것이다. 이러한 결과를 보다 광범위한 논 지에서 해석하자면 다음과 같다. 인지처리모델(cognitive processing model)에 기반하면, 읽기와 쓰기에서 각 경로의 역할은 유사하 지만 쓰기의 경우 자소-완충기(graphemic buffer)를 거쳐 이서단계 (allographic), 그 다음 계획 및 프로그래밍이 이루어지고 마지막 단 계는 손을 이용하여 최종적으로 글자를 만들어 내는 운동집행을 한다. 즉 쓰기가 수행되는 과정은 읽기에 비해 글자를 구성하는 개 개의 획을 산출하며, 다양한 획들을 조합하는 등 더 복잡한 단계의 인지언어 처리과정이 요구된다(Lee \& Yang, 2011; Park, 2013). 이러 한 처리과정은 집행기능에 속하며 여러 정보를 일시적으로 저장하 고 처리하는 작업기억과도 연관되어 있다(Baddeley, Logie, Bressi, Sala, \& Spinnler, 1986). 자소-완충기 (graphemic buffer) 즉, 중추 단 계를 통해 형성된 단어가 말초 처리 단계로 가기 직전에 임시적으 로 저장되는 단계에서 손상이 나타나면 쓰기-운동 단계를 통해 글 자가 산출되는 동안 임시로 저장되었던 단어의 자소 표상이 사라 져 자소 치환, 생략, 대치 등의 오류가 발생하기도 한다(Kim, 2012). 또한 쓰기는 듣기, 말하기, 읽기 기술을 기반으로 가장 마지막 단계 에 습득되는 기술이다(Johnson \& Myklebust, 1967). 따라서 읽기 에 비하여 더 복잡하고 고차원적인 처리과정이 수반되는 쓰기에서 뇌손상으로 인한 변화가 민감하게 반영된 것으로 볼 수 있다. 반면 에 본 결과에 대한 해석을 문어처리과정 내의 범주로 국한해본다 면, 읽기와 쓰기는 크게 이해와 표현으로 그 활동이 나뉘며 독립적 으로 수행될 때는 각각의 고유한 과정을 밟으면서 활동의 결과에 도달하게 된다(Park, 2007). 즉, 읽기에서 시각적 자소가 청각적 음 소로 변환되는 과정과 쓰기에서 청각적 음소가 시각적 자소로 변 환되는 과정이 서로 구분되어 있기 때문에 청각적 음소가 시각적 자소로 변환되는 단계의 선택적 손상으로 인해 읽기가 아닌 쓰기 과제의 수행만이 저하되었을 가능성이 있겠다.

마지막으로는 쓰기과제의 모든 조건 중에서 특히 비단어 조건에 서만 수행력이 저하되었다는 점에 주목할 필요가 있다. 본 연구에 포함된 실어증 없는 환자 11 명의 뇌영상 자료를 확인해본 결과, 모 두 병소의 일부가 실비안열 주변에 포함되어 있었다. 실비안열 주변
영역은 음운처리에 관련이 있는 것으로 알려져 있으므로(Cho \& Pyun, 2015; Fiez \& Petersen, 1998) 위의 근거들을 종합해볼 때, 뇌 손상이 문어의 음운정보처리와 관련이 있는 음운경로에 영향을 주게 되고 이러한 영향이 읽기에 비하여 인지적 부담이 가중되는 쓰기, 특히 비단어 쓰기에서 두드러지게 반영되는 것으로 생각해 볼 수 있다. 그러나 MRI 판독결과로 환자 집단을 피질병소 유형과 피질하병소 유형으로 대략적으로 분류하였을 때, 실어증 없는 집단 은 실어증 집단에 비하여 피질하구조에 병변이 있는 경우가 상대적 으로 높았다. 피질하구조는 피질구조에 비하여 인지처리과정에 덜 관여하는 것으로 알려져 있으나 피질하병소가 복잡한 과제의 인지 처리과정에 영향을 준다는 보고(Benke, Delazer, Bartha, \& Auer 2003; Nadeau \& Crosson, 1997; Radanovic \& Scaff, 2003)가 있다. 추후 병소 관련분석을 통하여 피질하구조의 정확한 병변 위치를 확인하고 실비안열 주변 영역과의 신경연결의 정도나 위치관계를 파악할 수 있다면 실어증 없는 집단의 비단어 쓰기 수행력이 저하 된 보다 명확한 근거를 확인하는 데 도움을 줄수 있겠다.

추가적으로 집단 내 단어조건에 따른 수행력을 비교한 결과, 읽 기과제에서 실어증 없는 환자군과 정상군은 세 단어 조건(규칙단 어와 불규칙단어, 비단어) 간에 유의한 차이를 보이지 않는 동일한 수행양상을 보였다. 읽기과제에서 실어증 없는 환자군이 정상군과 유사한 수행양상을 보인 것과 다르게 쓰기과제에서는 실어증 없는 환자군이 실어증 환자군과 유사하게 불규칙단어와 비단어 수행력 이 저하되는 양상을 보였다. 이렇게 과제에 따라 실어증 없는 환자 군이 정상군과 실어증 환자군과 각각 유사한 수행 양상을 보인 이 유로는 앞서 언급하였던 쓰기가 읽기보다 인지적으로 처리해야 하 는 과정이 더 많이 요구되어 언어장애 유무와 상관없이 뇌손상 자 체만으로 영향을 받았기 때문으로 설명할 수 있다. 또한 이와 유사 한 맥락에서 정상군 내의 단어조건에 따른 결과를 설명해보고자 한다. 정상군은 읽기에서 세 단어 조건(규칙단어, 불규칙단어, 비단 어) 간 유의한 차이가 나타나지 않았으나 쓰기에서는 규칙단어와 비단어에 비해 불규칙단어의 수행력이 유의하게 낮았다. 이는 정상 성인 집단에서 인지처리과정의 속도와 정확성에 영향을 받아 불규 칙단어 쓰기의 수행력이 상대적으로 저하됨을 보고한 선행연구 (Yoon \& Lee, 2014)와 유사한 결과이다. 한글은 대체로 자소와 음 소 사이에 1:1 대응을 원칙으로 하지만 단어 내 음절의 위치에 따라 음운변동이 적용되면서 글자와 다르게 발음되는 불규칙 조건이 존 재한다. 따라서 수행을 위해서는 낱자에 대한 지식뿐만 아니라 음 절과 단어 수준의 음운변동에 대한 지식이 요구되며(Kim, 2009), 그 지식에 기초한 음운변동의 적용여부에 따라 여러 개의 표상후 보(예: '피붙이'->/피부치///피부지/,/피붙지///피붙치/등) 중 올바른 
표상을 선택하기 위한 최종 결정 단계를 거치게 된다(Cho \& Nam, 2002). 따라서 정상인의 경우 이 과정에서 읽기보다 인지적 처리과 정의 복잡한 쓰기에서 그 어려움이 반영된 것으로 해석할 수 있다.

읽기과제 중 오류유형별로 살펴보면, 실어증 환자군은 규칙단어 에서 음운형태오류가 63.64\%로 높게 나타났다. 불규칙단어에서는 음운형태오류가 $57.14 \%$ 로 가장 높았으며, 그 다음으로 분류불가 $26.53 \%$ 로 높게 나타났다. 비단어에서는 음운형태오류가 $52.22 \%$ 로 높게 나타났으며, 그 다음으로 어휘화(21.11\%)가 높았다. 이는 철자 어휘집과 의미시스템, 음운어휘집을 거치는 어휘-의미 체계의 손상 으로 제시된 단어와 음운적으로 유사한 단어로 읽은 것으로 판단 된다. 불규칙단어는 자소와 음소가 대응되지 않아서 음운변동을 적용해야 하는 복잡한 인지처리과정에 해당되어 처리부담이 더 크 기 때문에 이를 어휘경로로 읽어도 오반응을 보이기 쉽고, 음운경 로로 읽기를 시도하여도 오반응을 보이게 될 가능성이 있다. 그러 므로 실어증 환자는 음운변동을 적용하려고 시도는 하였지만 이 를 잘못 적용(예: ‘피붙이'/피부치/->/피부지/) 한 것으로 보인다. 비 단어의 경우에는 비단어를 처음 보는 낯선 단어로 인식하고 비록 오류를 보일지라도 음소를 자소로 변환하는 과정을 거치는 전략 을 택하지만 실어증 환자군은 자소와 음소 1:1로 변환하는 과정을 시도하였으나 그 과정에서 손상이 더욱 심하게 나타나 부족한 음 운경로를 보완하기 위한 전략으로서 어휘경로를 사용하여 시각적 형태가 유사한 의미가 있는 단어를 선택하는 어휘화를 보였을 가 능성이 있겠다. 실어증 없는 환자군은 읽기과제 중 불규칙단어에서 는 음운형태오류가 $64.29 \%$ 로 가장 높았으며, 그 다음으로 규칙화 가 $35.71 \%$ 로 높게 나타났다. 불규칙단어는 앞서 언급한 것과 같이 규칙단어에 비해 복잡한 인지처리과정에 속하므로 좌반구 뇌손상 이 있는 실어증 없는 환자군은 이를 규칙화(예: '헐값[헐깝]->/헐 갑/)한 것으로 보인다. 비단어에서는 음운형태오류가 $96.30 \%$ 로 가 장 높게 나타났다. 이는 비단어를 낯선 단어임을 인식하고 자소-음 소 변환 경로인 음운경로를 통해 처리를 하려고 하였지만 그 과정 에서 손상이 나타나 단어의 음운조작을 필요로 하는 음운처리에 서 어려움을 겪고 음운대치, 음운삭제 등 음운적 오류를 보인 것으 로 판단된다. 정상군 또한 불규칙 단어에서 음운형태오류(56.25\%), 규칙화(43.75\%) 순으로 나타났다. 이는 불규칙단어가 규칙단어에 비해 억제, 주의집중과 같은 인지적 처리 단계가 더 많이 요구되므 로 어려움을 보인 것으로 판단된다.

쓰기과제 중 오류유형별로 살펴보면 규칙단어에서 실어증 환자 군은 음운형태오류가 $81.08 \%$ 로 가장 높았으며, 그 다음으로 분류 불가(18.92\%)가 나타났다. 음운형태오류 다음으로 분류불가가 많 이 나타났는데, 이는 실어증 환자군이 청각적 소리 이미지와 철자
정보를 연결하는 능력이 저하되어(Baik, 2004) 신조어를 포함한 분 류불가 오류가 나타난 것으로 생각해 볼 수 있다. 불규칙단어에서 는 음운형태오류가 $45.45 \%$ 로 가장 높았으며, 그 다음으로 소리 나 는 대로 쓴 오류가 $28.79 \%$ 로 높게 나타났다. 비단어에서는 음운형 태오류가 $52.27 \%$ 로 높게 나타났으며, 그 다음으로 어휘화(17.05\%) 가 높았다. 이는 앞서 언급한 것과 같이 일종의 보완전략으로 어휘 경로를 통해 쓰기를 시도하여 제시된 자극어와 비슷한 단어를(예: '줍-> (죽/) 산출한 것으로 보인다. 특히, 실어증 환자군은 읽기보다 쓰기에서 'DK', 'NR'오류가 많이 나타났다. 이는 환자 중 오른손잡 이이지만 마비로 인해 왼손으로 쓰는 경우와 단어 쓰기를 아예 시 도하지 않았거나 쓰려고 시도를 했음에도 불구하고 '모르겠다'라 고 쓰기를 포기하는 모습을 보여 이러한 결과로 인해 읽기보다 쓰 기에서 더욱 어려움이 나타난 것으로 판단된다. 실어증 없는 환자 군은 불규칙단어에서 소리 나는 대로 쓴 오류가 $51.67 \%$ 로 가장 높 았으며, 그 다음으로 음운형태오류 $35.00 \%$ 로 높게 나타났다. 정상 군 또한 소리 나는 대로 쓴 오류가 63.77\%로 가장 높았다. 특히, 쓰 기과제 중 불규칙단어에서 오류 빈도가 높게 나타났는데, 이는 앞 서 애기한 것과 같이 이는 자소와 음소 $1: 1$ 대응되지 않는 불규칙단 어에 음운변동을 적용하면서 동시에 작업기억 등 복잡한 인지기능 이 요구되는 쓰기 과정이 필요하기 때문에 처리부담을 느끼고 소리 나는 대로 쓰는 오류(예. '닿다'->/다타/, '괜찮다'->/괜찬타/)를 가 장 많이 보인 것으로 판단된다. 그러나 이러한 오류비율들은 통계 검정을 거치지 않고 단순히 수치를 제시한 것이므로 결과를 해석 하는데 주의가 필요하겠다.

본 연구는 한글의 단어조건과 인지처리모델에 근거하여 실어증 유무에 따른 읽기와쓰기능력 및 오류 양상을 살펴볼 수 있는 기초 자료를 제공하는 연구로서 뇌경색 환자의 경우 언어중추의 손상과 더불어 어휘경로, 음운경로의 손상이 읽기와 쓰기 수행에 영향을 주는 것을 확인하였다. 또한 실어증 환자군은 읽기에 비해 쓰기에 서 더욱 어려움을 보였으며, 실어증 없는 환자도 정상 성인보다 비 단어 쓰기의 수행이 저하됨을 확인하였다. 이는 쓰기가 다양한 인 지기능이 복합적으로 관여하는 고도의 인지 과정이기 때문에 뇌의 특정 부위에 손상이 있다면 실어증 동반여부와 관계없이 쓰기능력 에 변화가 올 수 있음을 시사한다. 좌반구 뇌손상환자는 우측 상하 지의 운동장애를 보일 수 있고 검사 시간의 제약 등으로 인하여 언 어평가 시 쓰기영역을 포함하지 않는 경우가 있다. 따라서 이러한 결과는 임상에서 뇌손상이나 실어증으로 인한 문어능력의 감퇴나 민감한 변화를 확인하고자 할 때, 읽기뿐만 아니라 쓰기능력 또한 면밀히 확인해야 하는 근거를 제시하였다는 점에서 연구의 임상적 의의가 있다. 
연구의 제한점은 다음과 같다. 본 연구에서는 환자의 MRI 판독 결과를 토대로 읽기와 쓰기의 경로에 손상이 있다고 예상하였지 만, 이러한 손상이 실제로 한글읽기 및 쓰기와 직접적인 관련이 있 는지 확인하기 위하여 후속연구에서는 뇌영상의 특정 관련 영역 분석(regions of interest)이 시행될 필요가 있겠다. 또한 환자군의 특정 실독증/실서증 유형의 비율이 유사하지 않아 이러한 하위 유 형에 따른 수행력과 오류유형을 비교해보지 않았다. 추후 다수의 환자를 대상으로 손상영역과 수행력에 따른 실독 및 실서증의 하 위유형을 분류하고 각 유형별 오류 양상을 확인할 수 있다면 한국 어 실독/실서증의 특성을 정립할 수 있겠다.

\section{REFERENCES}

Baddeley, A., Logie, R., Bressi, S., Sala, S. D., \& Spinnler, H. (1986). Dementia and working memory. The Quarterly Journal of Experimental Psychology Section A, 38, 603-618.

Baik, Y. (2004). Reading aloud of Chinese-derivative words and pure Korean words in aphasia with dyslexia (Master's thesis). Yonsei University, Seoul, Krea.

Benke, T., Delazer, M., Bartha, L., \& Auer, A. (2003). Basal ganglia lesions and the theory of fronto-subcortical loops: neuropsychological findings in two patients with left caudate lesions. Neurocase, 9, 70-85.

Chapey, R. (2008). Language intervention strategies in aphasia and related neurogenic communication disorders. Philadelphia, PA: Lippincott Williams \& Wilkins.

Chen, H., Cai, X., \& Gong, T. (2004). Agraphia without aphasia due to left cerebral hemispheric stroke in dextrals. Journal of Brain and Nervous Diseases, $12,002$.

Cho, H. Y. (2000). A study on Korean vocabulary education. Seoul: Pagijong.

Cho, H., \& Nam, K. (2002). Regularity effect shown in aphasic patients. Korean Journal of Communication \& Disorders, 7, 77-94.

Cho, H., \& Pyun, S. B. (2015). Characteristics of acquired phonological dyslexia in Korean. Communication Sciences \& Disorders, 20, 570-586.

Cho, K. (2005). A case study on the acquired Hangul dyslexia and dysgraphics. Seoul National University Journal of Humanities, 22, 161-179.

Cho, K., Jung, J., \& Nam, K. (2002). Lexical processing in acquired Hangul dyslexia. Korean Journal of Communication Disorders, 7, 1-20.

Choi, S. (2017). The phonological activation in Korean word and non-word recognition: evidence from event-related potential (Master's thesis). Ewah Womans University, Seoul, Korea.
Christensen, K. J., Multhaup, K. S., Nordstrom, S., \& Voss, K. (1991). A cognitive battery for dementia: development and measurement characteristics. Psychological Assessment: A Journal of Consulting and Clinical Psychology, 3, 168-174.

Ellis, A. W., \& Young, A. W. (1988). Human cognitive neuropsychology. Hillsdale, NJ: Lawrence Erlbaum Associates.

Ellis, A. W., \& Young, A. W. (1993). Human cognitive neuropsychology: a textbook with readings. London: Psychology Press.

Fayol, M., Zorman, M., \& Lt, B. (2009). Associations and dissociations in reading and spelling French: unexpectedly poor and good spellers. In Teaching and learning writing (pp. 63-75). London: British Psychological Society.

Fiez, J. A., \& Petersen, S. E. (1998). Neuroimaging studies of word reading. Proceedings of the National Academy of Sciences, 95, 914-921.

Gathercole, S. E., Willis, C. S., Baddeley, A. D., \& Emslie, H. (1994). The children's test of nonword repetition: a test of phonological working memory. Memory, 2, 103-127.

Ha, J. W., Pyun, S. B., Hwang, Y. M., Yi, H., \& Sim, H. S. (2013). A comparative study of spoken and written sentence production in adults with fluent aphasia. Phonetics and Speech Sciences, 5, 103-111.

Hanlon, R. E., Lux, W. E., \& Dromerick, A. W. (1999). Global aphasia without hemiparesis: language profiles and lesion distribution. Journal of Neurology, Neurosurgery \& Psychiatry, 66, 365-369.

Helm-Estabrooks, N. (2002). Cognition and aphasia: a discussion and a study. Journal of Communication Disorders, 35, 171-186.

Henry, M. L., Beeson, P. M., Stark, A. J., \& Rapcsak, S. Z. (2007). The role of left perisylvian cortical regions in spelling. Brain and Language, 100, 44-52.

Heo, H., Kwag, K. M., \& Lee, Y. (2011). The relationship among the reading and writing abilities and oral language skills of school-aged low-achievers in language learning. Korean Journal of Communication \& Disorders, 16, 23-33.

Hwang, J. E., Kim, H., Cho, S. R., \& Yoon, J. H. (2017). Word lexicality-and regularity-dependent alexia in Alzheimer's disease. Communication Sciences \& Disorders, 22, 129-137.

Johnson, D. J., \& Myklebust, H. R. (1967). Learning disabilities: educational principles and practices. New York, NY: Grune \& Stratton.

Jung, D. Y. (1993). The definitions and types of learning disabilities. Journal of Emotional \& Behavioral Disorders, 9, 1-9.

Kang, Y., Na, D. L., \& Hahn, S. (1997). A validity study on the Korean MiniMental State Examination (K-MMSE) in dementia patients. Journal of the Korean Neurological Association, 15, 300-308. 
Kee, B. S. (1996). A preliminary study for the standardization of geriatric depression scale short form-Korea version. Journal of Korean Neuropsychiatric Association, 35, 298-307.

Kim, A. H. (2009). Spelling skills of elementary students in Korea: focusing on spelling accuracy and error patterns. The Journal of Elementary Education, 22, 85-113.

Kim, A. T. (2002). Study on the systematization of teaching dictation for orthographic improvement (Master's thesis). Gyeongin National University of Education, Incheon, Korea.

Kim, H. (2012). Neurogenic speech-language disorders. Seoul: Sigmapress.

Kim, H., \& Cho, J. (2001). Phonological awareness, visual perception and reading of Hangul in preschool children. Korean Journal of Psychology: Development, 14, 15-28.

Kim, H., \& Na, D. L. (2001). Paradise-Korean version of Western Aphasia Battery (K-WAB). Seoul: Paradise Welfare Foundation.

Kim, H., \& Na, D. L. (2012). Paradise-Korean version of Western Aphasia Battery-Revised (PK-WAB_R). Seoul: Paradise Welfare Foundation.

Kim, M. (2012). Text comprehension and word recognition of Korean elementary school children with or without reading difficulties (Doctoral dissertation). Hallym University, Chuncheon, Korea.

Kim, M., \& Pae, S. (2011). The decoding development of Korean children in word reading. Korean Journal of Communication \& Disorders, 16, 143-153.

Kim, S. T. (2000). A study on the 'morphographemic writing. Journal of Linguistic Studies, (4), 47-61.

Kim, W. (2017). Comparison of reading performance between persons with aphasia and normal adults according to lexicality and regularity (Master's thesis). Ewha Womans University, Seoul, Korea.

Kim, Y., Park, J., \& Cha, H. (2011). Study to reading and writing ability of students with mental retardation. The Journal of Special Children Education, 13, 413-433.

Kimura, D. (1977). Acquisition of a motor skill after left-hemisphere damage. Brain, 100, 527-542.

Knollman-Porter, K., Wallace, S. E., Hux, K., Brown, J., \& Long, C. (2015). Reading experiences and use of supports by people with chronic aphasia. Aphasiology, 29, 1448-1472.

Kwon, J. C., Lee, H. J., Chin, J., Lee, Y. M., Kim, H., \& Na, D. L. (2002). Hanja alexia with agraphia after left posterior inferior temporal lobe infarction: a case study. Journal of Korean Medical Science, 17, 91.

Kwon, M., Kim, J. S., Lee, J. H., Sim, H., Nam, K., \& Park, H. (2005). Double dissociation of Hangul and Hanja reading in Korean patients with stroke.
European Neurology, 54, 199-203.

Kwon, Y. (2013). A study on relationship between executive attention and language ability in persons with aphasia (Master's thesis). Daegu University, Gyeongsan, Korea.

Langmore, S. E., \& Canter, G. J. (1983). Written spelling deficit of Broca’s aphasics. Brain and Language, 18, 293-314.

Lee, A., \& Yang, M. (2011). Research trends in writing ability: a review of research for students with and without writing difficulties. Korean Journal of Special Education, 46, 133-157.

Lee, B. W., Kwon, H. K., \& Lee, H. J. (2000). Clinical pictures of stroke patients. Journal of Korean Academy of Rehabilitation Medicine, 24, 370-374.

Lee, C. J., \& Kim, M. H. (2011). A serious game for language/cognitive rehabilitation therapy of stroke patients. Journal of Korea Entertainment Industry Association, 5, 73-80.

Lee, S. J., Lee, K. H., Kim, H., Kwon, M. S., Na, D. L., Chung, C. S., ... \& Kim, S. E. (2001). Striatocapsular infarct and aphasia. Journal of the Korean Neurological Association, 19, 10-18.

Lim, Y, K. (2006). A study on the applicability of phonological rules in Hangul word recognition (Master's thesis). Ewha Womans University, Seoul, Korea.

Marinelli, C. V., Spaccavento, S., Craca, A., Marangolo, P., \& Angelelli, P. (2017).

Different cognitive profiles of patients with severe aphasia. Behavioural Neurology, 2017, 1-15.

Ministry of Health and Welfare. (2017). Stroke clinic current situation. http:// www.mohw.go.kr/react/al/sal0301vw.jsp?PAR_MENU_ID=04\&MENU_ ID=0403\&CONT_SEQ=339009\&page=1

Moll, K., \& Landerl, K. (2009). Double dissociation between reading and spelling deficits. Scientific Studies of Reading, 13, 359-382.

Moon, H. (2001). Literacy and cognitive function in the Korean elderly subjects (Master's thesis). Sungshin Women's University, Seoul, Korea.

Na, D. L. (2016). Cognitive neurology \& neuropsychology for clinicians. Namyangju: Brain Beauty Publisher.

Nadeau, S. E., \& Crosson, B. (1997). Subcortical aphasia. Brain and Language, 58, 355-402.

Nadeau, S. E., Rothi, L. J., \& Crosson, B. (2000). Aphasia and language: theory to practice. New York, NY: Guilford Press.

Nam, K. C., Seo, K. J., Choi, K. S., Lee, K. G., Kim, T. H., \& Lee, M. Y. (1997). The word length effect on Hangul word recognition. Korean Journal of Experimental \& Cognitive Psychology, 9, 1-18.

National Institute of Korean Language. (2003). Korean a learning vocabulary. Seoul: Author. 
National Institute of Korean Language. (2005). Frequency in use of Modern Korean. Seoul: Author.

Olive, T., \& Kellogg, R. T. (2002). Concurrent activation of high-and low-level production processes in written composition. Memory \& Cognition, 30, 594-600.

Park, J. (2013). Writing performance capability and working memory capacity of school-age children with poor reading skills (Master's thesis). Catholic University of Pusan, Busan, Korea.

Park, Y. (2007). Correlational research on reading motivation and writing motivation. Research on Writing, 5, 105-134.

Patterson, K. E., \& Marcel, A. J. (1977). Aphasia, dyslexia and the phonological coding of written words. The Quarterly Journal of Experimental Psychology, 29, 307-318.

Piras, F., \& Marangolo, P. (2004). Independent access to phonological and orthographic lexical representations: a replication study. Neurocase, 10, 300307.

Platel, H., Lambert, J., Eustache, F., Cadet, B., Dary, M., Viader, F., \& Lechevalier, B. (1993). Characteristics and evolution of writing impairment in Alzheimer's disease. Neuropsychologia, 31, 1147-1158.

Radanovic, M., \& Scaff, M. (2003). Speech and language disturbances due to subcortical lesions. Brain and Language, 84, 337-352.

Radomski, M. V., \& Latham, C. A. T. (2008). Occupational therapy for physical dysfunction. Philadelphia, PA: Lippincott Williams \& Wilkins.

Rapcsak, S. Z., \& Beeson, P. M. (2004). The role of left posterior inferior temporal cortex in spelling. Neurology, 62, 2221-2229.

Rapp, B., \& Caramazza, A. (1997). The modality-specific organization of grammatical categories: evidence from impaired spoken and written sentence production. Brain and Language, 56, 248-286.

Rapp, B., \& Caramazza, A. (2002). Selective difficulties with spoken nouns and written verbs: a single case study. Journal of Neurolinguistics, 15, 373402.

Roeltgen, D. P., \& Heilman, K. M. (1984). Lexical agraphia: further support for the two-system hypothesis of linguistic agraphia. Brain, 107, 811-827.

Rosenbek, J. C., LaPointe, L. L., \& Wertz, R. T. (1989). Aphasia: a clinical ap- proach. Austin, TX: Pro-Ed.

Ryu, S. (2015). A study on the education Korean written language for children of multicultural families : based on the balanced language approach. The International Association for Korean Language Education, 256-282.

Sakurai, Y., Asami, M., \& Mannen, T. (2010). Alexia and agraphia with lesions of the angular and supramarginal gyri: evidence for the disruption of sequential processing. Journal of the Neurological Sciences, 288, 25-33.

Shallice, T. (1981). Phonological agraphia and the lexical route in writing. Brain, $104,413-429$.

Shin, J., \& Cha, J. (2003). Korean sound system. Seoul: Hangukmunwhasa.

Sinanović, O., Mrkonjić, Z., Zukić, S., Vidović, M., \& Imamović, K. (2011). Post-stroke language disorders. Acta Clin Croat, 50, 79-94.

Song, Y., \& Hong, J. (2015). Correlation between cognitive function or swallowing and activities of daily living in acute stroke patient. Journal of Rehabilitation Research, 19, 235-250.

Sung, S. (2010). Writing disorders in Alzheimer's disease: exploring the effect of word characteristics and type of stimulus (Master's thesis). Ewha Womans University, Seoul, Korea.

Yi, K. (1993a). On the role of frequency and internal structure in the processing of Kulca. Korean Journal of Experimental and Cognitive Psychology, 5, 26-39.

Yi, K. (1993b). Language and physiology. The Korean Association of Child Studies, 67-78.

Yim, E. K., Sung, Y. H., Lee, Y. B., Park, H. M., Shin, D. J., \& Park, K. H. (2008). Dissociation of Hangul and Hanja reading after left parieto-occipital infarction: alexia with agraphia with Hangul, but preserved in Hanja. Journal of the Korean Neurological Association, 26, 361-364.

Yoo, H. W. (2009). A study of the nominative case marker in Korean spoken language. Korean Semantics, 28, 147-169.

Yoon, J. H., \& Lee, E. O. (2014). Characteristics of orthographic retrieval with age in the elderly. Phonetics and Speech Sciences, 6, 119-125.

Yun, Y. H., Park, S. A., Park, J. H., Lee, T. K., Seok, H., \& Sung, K. B. (2009). Left subcortical infarction presenting pure agraphia. Journal of the Korean Neurological Association, 27, 393-397. 
Appendix 1. 환자 정보

\begin{tabular}{|c|c|c|c|c|c|c|}
\hline \multicolumn{7}{|c|}{ 실어증 환자군 } \\
\hline 대상자 & 성별 & 연령(세) & 교육년수(년) & 병소 부위 & $\mathrm{AQ}$ & 실어증 유형 \\
\hline 1 & 남 & 61 & 9 & Lt. MCA infarction & 78.8 & Anomic \\
\hline 2 & 남 & 55 & 12 & Lt. MCA infarction & 84.9 & Anomic \\
\hline 3 & 여 & 86 & 9 & Lt. CR infarction & 70.4 & Anomic \\
\hline 4 & 남 & 71 & 6 & Multiple infarction (Lt. MCA, PCA) & 79.1 & Transcorical sensory \\
\hline 5 & 남 & 80 & 9 & Lt. MCA territory infarction & 45.2 & Wernicke \\
\hline 6 & 여 & 86 & 6 & Lt. MCA infarction & 48.2 & Broca \\
\hline 7 & 남 & 79 & 6 & Lt. BG \& CR infarction & 87.5 & Anomic \\
\hline 8 & 남 & 81 & 6 & Lt. MCA infarction & 63.8 & Transcorical motor \\
\hline 9 & 남 & 61 & 6 & Lt. MCA infarction & 55.5 & Wernicke \\
\hline 10 & 남 & 50 & 14 & Lt. CR infarction & 91.0 & Anomic \\
\hline 11 & 남 & 62 & 6 & Lt. IC infarction & 89.8 & Anomic \\
\hline 12 & 남 & 56 & 16 & Lt. MCA \& Cbll infarction & 93.1 & Anomic \\
\hline 13 & 여 & 74 & 9 & Lt. MCA infarction & 34.2 & Wernicke \\
\hline \multicolumn{7}{|c|}{ 실어증 없는 환자군 } \\
\hline 대상자 & 성별 & 연령(세) & 교육년수(년) & 병소 부위 & $\mathrm{AQ}$ & 실어증 유형 \\
\hline 1 & 남 & 56 & 12 & Lt. BG \& CR infarction & 96.3 & - \\
\hline 2 & 남 & 60 & 12 & Lt. BG \& CR infarction & 98.1 & - \\
\hline 3 & 남 & 66 & 6 & Multiple infarction (Lt. ACA, MCA) & 93.3 & - \\
\hline 4 & 남 & 60 & 12 & Lt. BG \& CR infarction & 96.8 & - \\
\hline 5 & 남 & 77 & 16 & Lt. ACA infarction & 92.8 & - \\
\hline 6 & 여 & 64 & 9 & Lt. CR infarction & 98.4 & - \\
\hline 7 & 남 & 21 & 12 & Lt. BG infarction & 96.0 & - \\
\hline 8 & 여 & 77 & 6 & Lt. PCA infarction & 91.8 & - \\
\hline 9 & 남 & 81 & 16 & Lt. CR infarction & 97.6 & - \\
\hline 10 & 남 & 21 & 12 & Lt. thalamus \& Cbll infarction & 98.9 & - \\
\hline 11 & 남 & 58 & 9 & Lt. ACA territory infarction & 98.8 & - \\
\hline
\end{tabular}

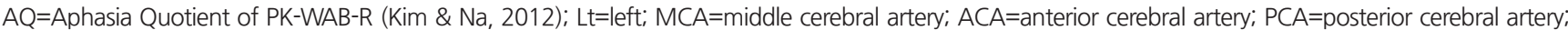
$\mathrm{BG}=$ basal ganglia; $\mathrm{CR}=$ corona radiata; $\mathrm{IC}=$ internal capsule; $\mathrm{Cb} \|=$ cerebellum. 
Appendix 2. 읽기, 쓰기 과제(규칙단어, 불규칙단어, 비단어) 목록

\begin{tabular}{|c|c|c|}
\hline \multicolumn{3}{|c|}{ 읽기 과제(60개) } \\
\hline 규칙단어(20개) & 불규칙단어(20개) & 비단어(20개) \\
\hline 이불 & 각하(가카) [격음화] & 도누 \\
\hline 감자 & 압력(암녁) [비음화] & 건머 \\
\hline 도깨비 & 미닫이(미다지) [구개음화] & 송티 \\
\hline 공책 & 특성(특썽) [경음화] & 다무내 \\
\hline 호수 & 권력(궐력) [유음화] & 포닌 \\
\hline 전통 & 넣다(너타) [격음화] & 본달 \\
\hline 시청자 & 철자(철짜) [경음화] & 컨비 \\
\hline 내용 & 낙하산(나카산) [격음화] & 호둑 \\
\hline 향기 & 헐값(헐깝)[자음군단순화, 경음화] & 정각체 \\
\hline 등산 & 식사(식싸) (경음화) & 누합 \\
\hline 방석 & 국민(궁민) [비음화] & 탕뚜 \\
\hline 타자기 & 피붙이(피부치) [구개음화] & 교진 \\
\hline 소원 & 복합(보캅) [격음화] & 살라메 \\
\hline 편지 & 전략(절략) [유음화] & 징덥 \\
\hline 마음 & 목화(모콰) [격음화] & 을바 \\
\hline 나비 & 독립(동닙) [비음화] & 펀자 \\
\hline 추석 & 갈대(갈때) [경음화] & 만더 \\
\hline 지갑 & 훈련(훌련) [유음화] & 놈제문 \\
\hline 발명 & 쌓다(싸타) [격음화] & 황드 \\
\hline 기상청 & 칡뿌리(칙뿌리) 자음군단순화] & 뻐말 \\
\hline \multicolumn{3}{|c|}{ 쓰기 과제(45개) } \\
\hline 규칙단어(15개) & 불규칙단어(15개) & 비단어(15개) \\
\hline 귤 & 능력(능녁)[비음화] & 밤누 \\
\hline 비누 & 덫(덛)[평폐쇄음화] & 콴 \\
\hline 송편 & 삼천리(삼철리) [유음화] & 탁치가 \\
\hline 뀡 & 입장(입짱) [경음화] & 우홉 \\
\hline 타조 & 국회(구쾨) [격음화] & 피국 \\
\hline 가지 & 솥(솓) [평폐쇄음화] & 눈별민 \\
\hline 창문 & 잡곡(잡꼭) [경음화] & 줍 \\
\hline 용 & 닿다(다타) [격음화] & 콘나 \\
\hline 다리미 & 괜찮다(관찬타) [자음군단순화, 격음화] & 머더지 \\
\hline 뺨 & 무릎(무릅)[평패쇄음화] & 석초 \\
\hline 저고리 & 칡(칙) (자음군단순화) & 톰 \\
\hline 노력 & 목련(몽년) [비음화] & 누할 \\
\hline 야구 & 쇠붙이(쇠부치) [구개음화] & 곡참 \\
\hline 하늘 & 닭발(닥빨) [자음군단순화, 경음화] & 웍 \\
\hline 주사위 & 몫(목) [자음군단순화] & 창니 \\
\hline
\end{tabular}


Appendix 3. 읽기 오류 유형 분석 기준

\begin{tabular}{|c|c|c|c|}
\hline 단어 & 유형 & 정의 & 목표단어 -> 오류 예시 \\
\hline \multirow[t]{4}{*}{ 규칙단어 } & 음운 형태 오류(Phonologically implausible error) & $\begin{array}{l}\text { 피험자의 반응이 맞춤법에서 벗어날 뿐만 아니라 목표 단어의 } \\
\text { 발음과도 다르게 읽은 경우 }\end{array}$ & $\begin{array}{l}\text { 발명->/병명/ } \\
\text { 지갑->/지감/ }\end{array}$ \\
\hline & 분류불가(신조어포함) & 분류할 수 없는 기타의 경우(알아들을 수 없는 경우 포함) & $\begin{array}{c}\text { 지갑->/감자/ } \\
\text { 기상청->/사람/ }\end{array}$ \\
\hline & DK & ‘모르겠다’ 대답할 경우 & - \\
\hline & NR & 무반응 & - \\
\hline \multirow[t]{5}{*}{ 불규칙단어 } & 음운 형태 오류(Phonologically implausible error) & $\begin{array}{l}\text { 피험자의 반응이 맞춤법에서 벗어날 뿐만 아니라 목표 단어의 } \\
\text { 발음과도 다르게 읽은 경우 }\end{array}$ & $\begin{array}{l}\text { 식사[식싸]->/석사/ } \\
\text { 철자[철짜]->철새/ }\end{array}$ \\
\hline & 규칙화(글자 그대로 읽는 오류) & 음운변동을 적용하지 않고 제시된 글자를 그대로 읽는 경우 & $\begin{array}{l}\text { 철자[철짜]->/철자/ } \\
\text { 헐값[헐깝]->/헐갑/ }\end{array}$ \\
\hline & 분류불가(신조어포함) & 분류할 수 없는 기타의 경우(알아들을 수 없는 경우 포함) & $\begin{array}{l}\text { 낙하산[나카산]->/라사안/ } \\
\quad \text { 권력[궐력]->/권눅/ }\end{array}$ \\
\hline & DK & ‘모르겠다’ 대답할 경우 & - \\
\hline & NR & 무반응 & - \\
\hline \multirow[t]{5}{*}{ 비단어 } & 음운 형태 오류(Phonologically implausible error) & $\begin{array}{l}\text { 피험자의 반응이 맞춤법에서 벗어날 뿐만 아니라 목표 단어의 } \\
\text { 발음과도 다르게 읽은 경우 }\end{array}$ & $\begin{array}{l}\text { 탕뚜->/탕두/ } \\
\text { 을바->/을빠/ }\end{array}$ \\
\hline & 어휘화 & 비단어를 단어로 읽은 경우 & $\begin{array}{l}\text { 호둑->/호두/ } \\
\text { 컨비->/커피// }\end{array}$ \\
\hline & 분류불가 & 분류할 수 없는 기타의 경우(알아들을 수 없는 경우 포함) & $\begin{array}{l}\text { 징덥->/징마/ } \\
\text { 송티->/송터니/ }\end{array}$ \\
\hline & DK & ‘모르겠다’ 대답할 경우 & - \\
\hline & NR & 무반응 & - \\
\hline
\end{tabular}

Hwang, Kim, Cho, \& Yoon (2017), Platel et al. (1993), Kim (2002), Sung (2010)에서 인용, 연구자 부분 수정. 
Appendix 4. 쓰기 오류 유형 분석 기준

\begin{tabular}{|c|c|c|c|}
\hline 단어 & 유형 & 정의 & 목표단어 $->$ 오류 예시 \\
\hline \multirow[t]{5}{*}{ 규칙단어 } & $\begin{array}{l}\text { 소리나는 대로 쓴 오류(Phonologically plausible } \\
\text { error) }\end{array}$ & $\begin{array}{l}\text { 피험자가 맞춤법에 틀린 오반응을 보였지만 해당 단어의 발음에 } \\
\text { 따라 글자 쓴 경우 }\end{array}$ & - \\
\hline & 음운 형태 오류(Phonologically implausible error) & $\begin{array}{l}\text { 피험자의 반응이 맞춤법에서 벗어날 뿐만 아니라 목표 단어의 발음 } \\
\text { 과도 다르게 쓴 경우 }\end{array}$ & $\begin{array}{l}\text { 창문->/탕문/ } \\
\text { 타조->/차조/ }\end{array}$ \\
\hline & 분류불가(신조어포함) & 분류할 수 없는 기타의 경우(글씨체를 알아볼 수 없는 경우 포함) & $\begin{array}{l}\text { 귤->/그/ } \\
\text { 뺨->/바/ }\end{array}$ \\
\hline & DK & ‘모르겠다' 대답할 경우 & - \\
\hline & NR & 무반응 & - \\
\hline \multirow[t]{5}{*}{ 불규칙단어 } & $\begin{array}{l}\text { 소리나는 대로 쓴 오류(Phonologically plausible } \\
\text { error) }\end{array}$ & $\begin{array}{l}\text { 피험자가 맞춤법에 틀린 오반응을 보였지만 해당 단어의 발음에 } \\
\text { 따라 글자 쓴 경우 }\end{array}$ & $\begin{array}{l}\text { 입장->/입짱/ } \\
\text { 닿다->/다타/ }\end{array}$ \\
\hline & 음운 형태 오류(Phonologically implausible error) & $\begin{array}{l}\text { 피험자의 반응이 맞춤법에서 벗어날 뿐만 아니라 목표 단어의 발음 } \\
\text { 과도 다르게 쓴 경우 }\end{array}$ & $\begin{array}{l}\text { 능력->/누력/ } \\
\text { 덧->/텃/ }\end{array}$ \\
\hline & 분류불가(신조어포함) & 분류할 수 없는 기타의 경우(글씨체를 알아볼 수 없는 경우 포함) & $\begin{array}{l}\text { 닭발->/갑말/ } \\
\text { 무릎->/뒤슬/ }\end{array}$ \\
\hline & DK & '모르겠다’ 대답할 경우 & - \\
\hline & NR & 무반응 & - \\
\hline \multirow[t]{6}{*}{ 비단어 } & $\begin{array}{l}\text { 소리나는 대로 쓴 오류(Phonologically plausible } \\
\text { error) }\end{array}$ & $\begin{array}{l}\text { 피험자가 맞춤법에 틀린 오반응을 보였지만 해당 단어의 발음에 } \\
\text { 따라 글자 쓴 경우 }\end{array}$ & - \\
\hline & 음운 형태 오류(Phonologically implausible error) & $\begin{array}{l}\text { 피험자의 반응이 맞춤법에서 벗어날 뿐만 아니라 목표 단어의 발음 } \\
\text { 과도 다르게 쓴 경우 }\end{array}$ & $\begin{array}{l}\text { 우홉->/우홈/ } \\
\text { 피국->/피굽/ }\end{array}$ \\
\hline & 어휘화 & 비단어를 단어로 쓴 경우 & $\begin{array}{l}\text { 줍->/죽/ } \\
\text { 톰->/통/ }\end{array}$ \\
\hline & 분류불가 & 분류할 수 없는 기타의 경우(글씨체를 알아볼 수 없는 경우 포함) & $\begin{array}{l}\text { 창니->/타이/ } \\
\text { 밤누->/단느/ }\end{array}$ \\
\hline & DK & '모르겠다' 대답할 경우 & - \\
\hline & NR & 무반응 & - \\
\hline
\end{tabular}

Platel et al. (1993), Kim (2002), Sung (2010)에서 인용, 연구자 부분 수정. 


\section{국문초록}

\section{실어증 유무에 따른 뇌경색 환자의 읽기와 쓰기 특성}

연은주 ${ }^{1} \cdot$ 김여진 ${ }^{2}$ 나덕렬 ${ }^{3}$ 윤지혜 ${ }^{4}$

한림대학교 보건과학대학원 언어병리학과, ${ }^{2}$ 한림대학교 춘천성심병원 신경과, ${ }^{3}$ 삼성서울병원 신경과, ${ }^{4}$ 한림대학교 언어청각학부

배경 및 목적: 좌반구 손상이 있더라도 언어 관련 영역이 침범되지 않으면 실어증이 동반되지 않을 수 있고, 뇌손상으로 인한 인지능력 의 변화로 실어증이 없는 상태에서도 실독증과 실서증이 발생할 가능성이 있다. 본 연구에서는 좌반구 뇌경색 환자를 대상으로 실어증 유무에 따른 읽기와 쓰기 수행력 및 오류 양상을 살펴보았다. 방법: 좌반구 뇌경색 환자 24 명(실어증 환자 13 명, 실어증 없는 환자 11 명), 정상 성인 15 명을 대상으로 60 개의 단어읽기 과제와 45 개의 단어쓰기 과제를 시행하였다. 결과: 첫째, 실어증 환자군이 실어증 없는 환 자군, 정상군보다 읽기(불규칙단어, 비단어)와 쓰기(규칙단어, 불규칙단어, 비단어) 과제에서 유의하게 낮은 수행력을 보였다. 둘째, 실 어증 없는 환자군은 정상군보다 쓰기(비단어) 과제에서 유의하게 낮은 수행력을 보였다. 논의 및 결론: 환자군은 언어능력의 손상으로 인해 문어능력인 읽기와쓰기에서도 어려움을 겪는 것으로 판단된다. 특히, 실어증 환자와 더불어 실어증 없는 뇌손상 환자도 정상 성인 에 비해 쓰기 과제에서 비단어 수행력이 낮게 나타났다. 이는 쓰기 과제가 읽기 과제보다 더 복잡하고 고차원적인 처리과정이 수반되 며, 비단어의 경우 주로 음운경로를 통해 처리가 이루어지므로, 실어증 여부와 상관없이 뇌손상이 자소-음소 간의 변환과정에 영향을 주었을 가능성을 시사한다.

핵심어: 뇌경색, 실어증, 실독증, 실서증

본 논문은 2017년 정부(산업통상자원부)의 재원으로 한국산업기술평가관리원의 지원을 받아수행된 연구임(No. 10063384).

본 논문은 2018년도 한림대학교 교비연구비(No. HRF-201806-009)에 의하여 연구되었음.

\section{참고문헌}

나덕렬(2016). 임상가를 위한 인지신경학, 신경심리학. 남양주: 뇌미인.

남기춘, 서광준, 최기선, 이경인, 김태훈, 이미영(1997). 한글 단어 재인에서의 단어길이 효과. 한국심리학회지, 9, 1-18.

백여정(2004). 실독증 환자들의 한자어와 고유어 소리내어 읽기 비교. 연세대학교 대학원 석사학위논문.

윤영훈, 박선아, 박정호, 이태경, 석현, 성기범(2009). 순수실서증으로 발현한 좌측 피질하 뇌경색. 대한신경과학회지, 27, 393-397.

윤지혜, 이은옥(2014). 정상 노인의 연령에 따른 철자 산출 특성. 말소리와음성과학, 6, 119-125.

임은광, 성영희, 이영배, 박현미, 신동진, 박기형(2008). 좌측 마루-뒤통수엽 뇌경색 후에 나타난 한글과 한자의 해리 현상. 대한신경과학회지, 26, 361-

364.

조경덕, 정재범, 남기춘(2002). 후천성 한글 난독증의 어휘처리 양상: 읽기, 명명, 쓰기 장애에 대한 사례연구를 중심으로. 언어청각장애연구, 7, 1-20.

조혜숙, 남기춘(2002). 실어증 환자에서 보이는 단어규칙성 효과. 언어청각장애연구, 7, 77-94.

조혜숙, 편성범(2015). 한국어 후천성 음운성 실독증의 특성. 언어청각장애연구, 20, 570-586.

황자은, 김향희, 조성래, 윤지혜(2017). 알츠하이머성 치매의 단어 어휘성 및 규칙성에 따른 실독증. 언어청각장애연구, 22, 129-137. 